Review

\title{
Modeling European ruminant production systems: Facing the challenges of climate change
}

\author{
Richard P. Kipling a,*, André Bannink ${ }^{\mathrm{b}}$, Gianni Bellocchi ${ }^{\mathrm{c}}$, Tommy Dalgaard ${ }^{\mathrm{d}}$, Naomi J. Fox ${ }^{\mathrm{e}}$, \\ Nicholas J. Hutchings ${ }^{\mathrm{d}}$, Chris Kjeldsen ${ }^{\mathrm{d}}$, Nicola Lacetera ${ }^{\mathrm{f}}$, Franz Sinabell ${ }^{\mathrm{g}}$, Cairistiona F.E. Topp ${ }^{\mathrm{e}}$, \\ Marcel van Oijen ${ }^{\mathrm{h}}$, Perttu Virkajärvi ${ }^{\mathrm{i}}$, Nigel D. Scollan ${ }^{\mathrm{a}}$
}

a IBERS, Aberystwyth University, 1st Floor, Stapledon Building, Plas Gogerddan, Aberystwyth, Ceredigion SY23 3EE, UK

${ }^{\mathrm{b}}$ Wageningen UR Livestock Research, P.O. Box 338, 6700 AH Wageningen, The Netherlands

' UREP, INRA, 63000 Clermont-Ferrand, France

d Department of Agroecology, Aarhus University, Blichers Allé 20, P.O. Box 50, DK-8830 Tjele, Denmark

e SRUC, West Mains Road, Edinburgh EH9 3JG, UK

${ }^{\mathrm{f}}$ Department of Agriculture and Forestry Science, University of Tuscia, Via San Camillo de Lellis, 01100 Viterbo, Italy

${ }^{g}$ Austrian Institute of Economic Research (WIFO), Arsenal - Objekt 20, 1030 Vienna, Austria

${ }^{\text {h }}$ CEH-Edinburgh, Bush Estate, Penicuik EH26 0QB, UK

${ }^{i}$ Vihreä Teknologia, Luonnonvarakeskus (Luke), Halolantie 31 A, 71750 Maaninka, Finland

\section{A R T I C L E I N F O}

\section{Article history:}

Received 4 January 2016

Received in revised form 9 May 2016

Accepted 9 May 2016

Available online $\mathrm{xxxx}$

\section{Keywords:}

Food security

Livestock systems

Modeling

Pastoral systems

Policy support

Ruminants

\begin{abstract}
A B S T R A C T
Ruminant production systems are important producers of food, support rural communities and culture, and help to maintain a range of ecosystem services including the sequestering of carbon in grassland soils. However, these systems also contribute significantly to climate change through greenhouse gas (GHG) emissions, while intensification of production has driven biodiversity and nutrient loss, and soil degradation. Modeling can offer insights into the complexity underlying the relationships between climate change, management and policy choices, food production, and the maintenance of ecosystem services. This paper 1) provides an overview of how ruminant systems modeling supports the efforts of stakeholders and policymakers to predict, mitigate and adapt to climate change and 2) provides ideas for enhancing modeling to fulfil this role. Many grassland models can predict plant growth, yield and GHG emissions from mono-specific swards, but modeling multi-species swards, grassland quality and the impact of management changes requires further development. Current livestock models provide a good basis for predicting animal production; linking these with models of animal health and disease is a priority. Farm-scale modeling provides tools for policymakers to predict the emissions of GHG and other pollutants from livestock farms, and to support the management decisions of farmers from environmental and economic standpoints. Other models focus on how policy and associated management changes affect a range of economic and environmental variables at regional, national and European scales. Models at larger scales generally utilise more empirical approaches than those applied at animal, field and farm-scales and include assumptions which may not be valid under climate change conditions. It is therefore important to continue to develop more realistic representations of processes in regional and global models, using the understanding gained from finer-scale modeling. An iterative process of model development, in which lessons learnt from mechanistic models are applied to develop 'smart' empirical modeling, may overcome the trade-off between complexity and usability. Developing the modeling capacity to tackle the complex challenges related to climate change, is reliant on closer links between modelers and experimental researchers, and also requires knowledge-sharing and increasing technical compatibility across modeling disciplines. Stakeholder engagement throughout the process of model development and application is vital for the creation of relevant models, and important in reducing problems related to the interpretation of modeling outcomes. Enabling modeling to meet the demands of policymakers and other stakeholders under climate change will require collaboration within adequately-resourced, long-term inter-disciplinary research networks.
\end{abstract}

(c) 2016 Elsevier Ltd. All rights reserved.

\footnotetext{
* Corresponding author.

E-mail addresses: rpk@aber.ac.uk (R.P. Kipling), andre.bannink@wur.nl (A. Bannink), gianni.bellocchi@clermont.inra.fr (G. Bellocchi), tommy.dalgaard@agro.au.dk (T. Dalgaard),

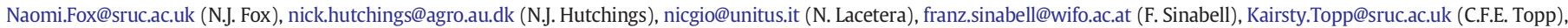
mvano@ceh.ac.uk (M. van Oijen), perttu.virkajarvi@luke.fi (P. Virkajärvi), ngs@aber.ac.uk (N.D. Scollan).
} 


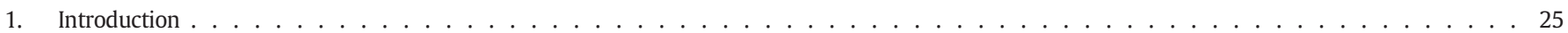

2. Modeling the impacts of climate change on ruminant livestock systems . . . . . . . . . . . . . . . . . . . . . . 25

2.1. Modeling livestock pathogens and disease . . . . . . . . . . . . . . . . . . . . . . . . . . . . . 25

2.2. Modeling heat stress in cattle . . . . . . . . . . . . . . . . . . . . . . . . . . . . 27

2.3. Modeling grassland productivity and nutritional value . . . . . . . . . . . . . . . . . . . . . . . . . 28

2.4. Modeling grassland biodiversity and interactions with productivity . . . . . . . . . . . . . . . . . . . . 28

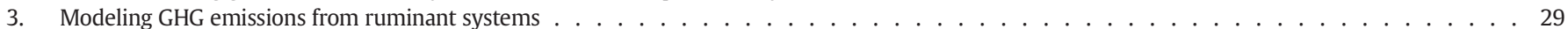

3.1. Farm-scale GHG emissions . . . . . . . . . . . . . . . . . . . . . . . . . . . . . . . . . . 29

3.2. Modeling carbon sequestration in grassland soils . . . . . . . . . . . . . . . . . . . . . . . . . . . . . . . . 29

3.3. Environmental impacts beyond the farm . . . . . . . . . . . . . . . . . . . . . . . . .

4. Regional and global economic modeling of livestock systems . . . . . . . . . . . . . . . . . . . . . . . . . . . . . . . 30

5. Stakeholders and modeling . . . . . . . . . . . . . . . . . . . . . . . . . . . . . . . . . .

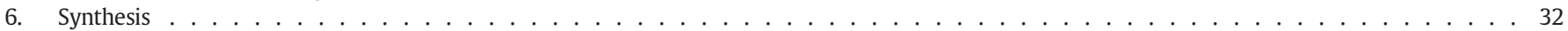

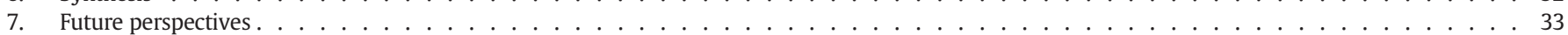

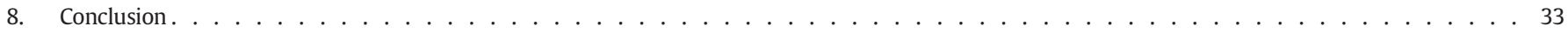

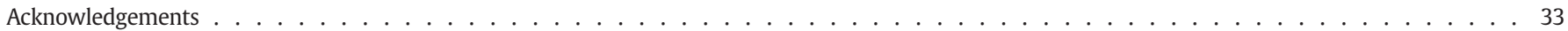

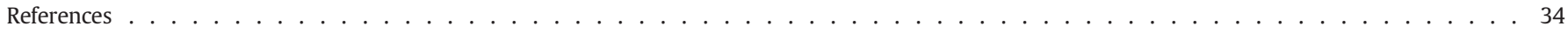

\section{Introduction}

The world's livestock production systems are facing unprecedented challenges - the need to reduce greenhouse gas (GHG) emissions, currently estimated to represent $15 \%$ of global anthropogenic emissions (Ripple et al., 2014), to adapt to global climatic and socio-economic changes (Soussana, 2014; Thornton, 2010), to provide ecosystem services, and to meet the expected rapid increase in demand for meat and dairy products resulting from changes in human diets in the developing world (Tilman and Clark, 2014). In order to avoid significant environmental costs, these goals must be reached through increased production efficiency to avoid further encroachment of agriculture into pristine natural ecosystems (Popp et al., 2014).

Several major global and European reports have mapped the strategic research areas in which progress is required to overcome the challenges to livestock production systems (ATF, 2013, 2014; FACCE-JPI, 2012; Soussana, 2014). All highlight the need for research that takes account of interactions between agricultural systems, between these systems and natural ecosystems, and between strategic policy choices and on-farm management decisions.

Assessments of how climate change, policy, management, and socioeconomic factors impact livestock production, require an understanding of complex systems beyond that possible through direct analysis of empirical data. In this respect, mathematical modeling has an essential role in the process of developing production systems capable of overcoming the multi-faceted problems described (Graux et al., 2013; Kipling et al., 2014). The aforementioned strategic research agendas represent challenges that the livestock and grassland modeling community must address if it is to play the role required of it by society (Scholten, 2015).

For modelers of ruminant production systems, the complexity of farm-scale interactions creates a major challenge for the scaling up of 'animal' and 'field' scale modeling to the national, regional and global levels most relevant for policy makers. A range of modeling approaches has been applied to European ruminant livestock systems and their various components (Box 1) with a number of technical reviews providing comprehensive comparisons of a range of models, for example (Holzworth et al., 2015; Snow et al., 2014; Tedeschi et al., 2014).

A recent review of modeling of grazed agricultural systems (Snow et al., 2014) highlighted the need for better modeling of extreme events, animal-mediated nutrient transfers, pests, weeds and gene-environment interactions. The present paper provides a strategic overview of ruminant production systems modeling in Europe in the context of climate change. The focus on Europe reflects the continent's large agricultural sector and its importation of agricultural products, which make it a major contributor to agricultural GHG emissions (Davis and Caldeira,
2010), while its recognition of the serious impacts of climate change make it a key location for research and innovation related to food security (Soussana et al., 2012a). The overview of ruminant production systems modeling presented here (Fig. 1) includes consideration of stakeholder engagement in the modeling process, and the role of economic modeling (at farm, regional and global scale). The purpose is: 1) to provide an overview of how current ruminant systems modeling supports the efforts of stakeholders and policymakers to predict, mitigate, and adapt to climate change and 2) to provide ideas about how modeling resources can be enhanced to best meet these challenges.

In relation to climate change, models of ruminant systems can be divided into those that focus on the impacts of climate change on such systems (Section 2), and those that focus on emissions of GHGs from them (Section 3). At the regional and global levels, economic modeling seeks to gain an overview of both of these processes and the interactions between them, in order to inform policy choices (Section 4), while engagement with stakeholders is essential to ensuring that modeling has a positive real-world impact (Section 5). Section 6 considers how best to overcome the challenges to the integration of these different aspects of modeling, and recommends some priorities for action.

\section{Modeling the impacts of climate change on ruminant livestock systems}

Climate change is expected to have a range of impacts on ruminant production systems, including the direct effects of changing conditions on grass and feed crop production (such as changing yields and quality) and livestock health (such as increased heat stress) and indirectly, for example through impacts on livestock pathogens, and pests affecting grasses and other crops. Section 2 explores some of the main climate change impacts and the state of modeling in relation to each.

\subsection{Modeling livestock pathogens and disease}

Climate change has already affected patterns of livestock disease (Kenyon et al., 2009; Purse et al., 2005; Wilson and Mellor, 2008), and further changes are predicted (Fox et al., 2015, 2011; van Dijk et al., 2008). A variety of climatic factors influence pathogen survival and development, including moisture, temperature and UV levels (Chaparro et al., 2011; O'Connor et al., 2006; Stromberg, 1997; van Dijk et al., 2009). These variables affect spatial distribution, parasite and disease intensity, and seasonal patterns of infection (Fox et al., 2011). Climate change will not influence all pathogens equally. Vector-borne parasites are especially sensitive to climate, as vector lifecycles and vectorial capacity are strongly influenced by abiotic conditions (Purse et al., 2005; Wilson 
Box 1

Description of technical aspects of agricultural models including the characteristics of the modeling areas described in this paper.

Empirical and mechanistic modeling: Empirical models derive from fitting statistical functions to experimental response data. Their accuracy is dependent on the characteristics of the datasets used to define the modeled relationship. They can be used to predict new conditions as determined by changes in the variables considered. However, they cannot respond to changes which might affect the nature of the statistical relationships they are based on. Empirical models may therefore provide inaccurate predictions when the values of the modeled variables are beyond the range for which the relationship was tested. Mechanistic approaches model the underlying mechanisms that drive observed empirical relationships, and can therefore reveal and explain unexpected systemic responses to future change. However, they cannot predict changes arising from the effects of un-modeled processes, which may become relevant under altered systemic conditions. In some cases, the variables used to derive empirical models can incorporate mechanistic understanding, blurring the distinction between the two approaches. Models often use a mixture of empirical and mechanistic approaches to characterise different relationships, so that there is a continuum between relatively mechanistic and relatively empirical modeling.

Time and variation: Models can be dynamic, to investigate how systems change over time, or static (not considering time as a variable). They can be deterministic (giving unique predictions) or stochastic (including random variation and reporting the dispersion as well as the predicted value of output variables).

Scale and complexity: As scale increases so does systemic complexity, as the number of variables and interactions between them rises at an increasing rate. Using mechanistic models at increasing scales (from plot or animal upwards) therefore requires increasing effort (in terms of systemic understanding and computing power) and involves increasing uncertainty. At the same time, some processes average out at larger scales, and can be represented by simpler functions. These factors mean that more empirical approaches are used as the scale of the modeled system increases.

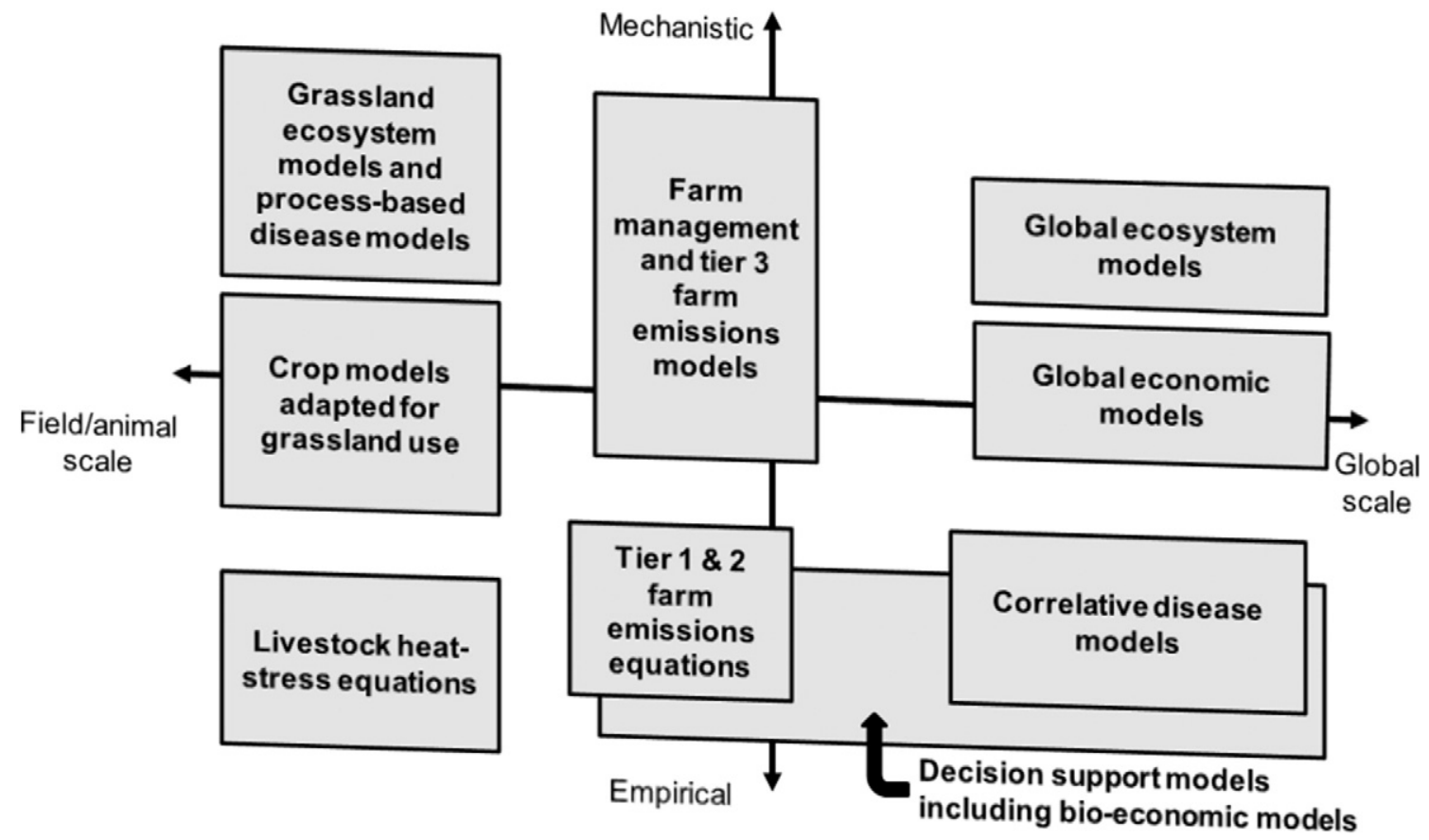

Chart: Some groups of models associated with ruminant production systems, showing their scale of focus and modeling approach. Model groups are those discussed in this paper, addressing aspects felt to be most relevant in the context of climate change

and Mellor, 2008). Climate change is also having profound impacts on macro-parasites (Broughan and Wall, 2007; Fox et al., 2011), as survival and development of their free-living stages are governed by temperature and moisture availability. Despite potential for pathogen outbreaks to compromise food security and animal welfare, there are few predictions of future disease risk in livestock (Fox et al., 2012). In this context, modeling is a vital tool for understanding how climate change will affect pathogen risk, supporting the development of effective prevention and control measures.

Predictive species distribution models are often based on correlative ecological niche models in which species' environmental requirements are inferred from current geographic distributions (Elith and Leathwick, 2009; Heikkinen et al., 2006; Pagel and Schurr, 2012). Insights into the biology of parasite dynamics should be used to improve and parameterize these models, and to choose the most proximal environmental predictors (Guisan and Thuiller, 2005). Correlative modeling has already provided projections of future risk for livestock pathogens including vector borne Blue Tongue Virus (Tatem et al., 2003) and liver fluke, which spends large parts of its lifecycle outside its definitive host (Fox et al., 2011). A bottleneck for developing models for a broader range of species is the limited availability of pathogen distribution data. Additionally, correlative models do not contain underlying dynamical processes, rapidly accruing uncertainty when projected climate change forces extrapolation (Fox et al., 2012). To overcome this limitation, and to identify potential for qualitative shifts in system behaviour, a process-based mechanistic approach is needed. Mechanistic models 


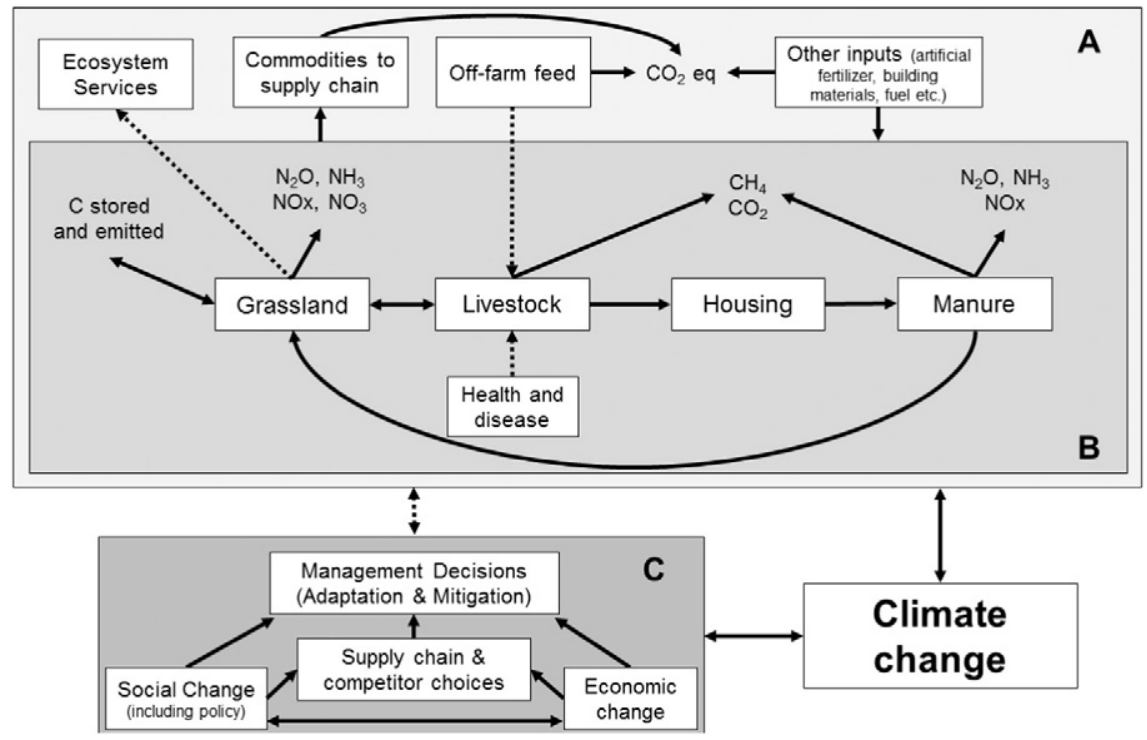

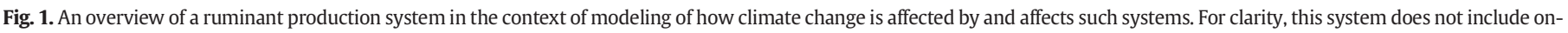

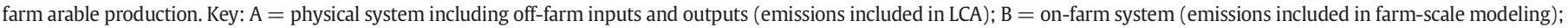
$\mathrm{C}=$ impacts of changes in management and its drivers; dashed lines $=$ relationships requiring further development in models

are based on detailed knowledge of host and pathogen physiology and attempt to replicate underlying mechanisms that drive species' responses to environmental variables (Robertson et al., 2003). As such models do not rely on empirical relationships between climate variables that may alter with climate change, they are comparatively robust under spatio-temporal extrapolation (Dormann, 2007; Hijmans and Graham, 2006) and can predict consequences of subtle interactions between system components under climate influence. Fox et al. (2015) used a process-based model to demonstrate that small temperature changes around critical thresholds can drive sudden changes in nematode risk in grazing livestock. There is now a need to parameterize such models for particular pathogens, and apply them to specific farming systems under climate change projections.

At the farm level, husbandry has a dominant influence on disease transmission (Fox et al., 2013; Smith et al., 2009); long term predictive models therefore need to incorporate the effects of management responses to climate change. An optimal modeling approach is likely to combine mechanistic processes and physiological thresholds with correlative bioclimatic modeling, incorporating changes in livestock husbandry and disease control. Despite recent advances in statistical methodologies, model-fitting and climate projections, progress remains limited by the paucity of active surveillance data, and empirical data on physiological responses to climate variables. By combining improved empirical data and refined models with a broad view of livestock systems, robust projections of livestock disease risk can be developed.

\subsection{Modeling heat stress in cattle}

High and extreme temperatures, in combination with other factors such as humidity and solar radiation, are known to cause heat stress in a range of domestic animals, with effects on productivity, growth, development (Collier and Gebremedhin, 2015) and reproduction (de Rensis et al., 2015). The Temperature Humidity Index (THI) has been widely used to explore these relationships in livestock, and to model expected responses to climatic change (Gaughan and Hahn, 2010). THI has some recognised limitations, including the assumption that all animals respond to thermal stressors in the same way, and a lack of consideration of other important variables (including solar radiation, wind speed, duration of exposure) (Gaughan et al., 2012). Improved indices have been proposed, including THI adjusted for wind speed and solar radiation, a number of respiration rate indices and the heat load index
(Gaughan et al., 2012). Whatever the index used, climate change is expected to raise average temperatures and increase the frequency of temperature extremes. Heatwaves are predicted to become more frequent, particularly in Southern Europe and the Mediterranean, with expected decreases in relative humidity away from the coasts unlikely to offset the impacts of increased temperature (Fischer and Schar, 2010). As a result, increases are expected in the number of days when THI in Europe exceeds calculated thresholds for heat stress in dairy cattle (Dunn et al., 2014; Segnalini et al., 2013).

Mechanistic models have been developed to characterise heat flows and changes in body temperature in cattle (Thompson et al., 2014) and thermal balance in pigs and poultry (Mitchell, 2006), while empirical equations are used to model the negative relationship between increases in THI above calculated thresholds, dairy cow milk yield and milk composition (Bertocchi et al., 2014; Bohmanova et al., 2007; Gorniak et al., 2014; Hammami et al., 2013; Hill and Wall, 2015) and dairy and beef cattle mortality (Morignat et al., 2015; Vitali et al., 2009). Models are also used to test the design of livestock housing in relation to airflow and temperature (Herbut and Angrecka, 2015) and to model the temperature effects on animals of other physical variables such as bedding type (Radoń et al., 2014).

Although the empirical modeling of thermal comfort zones and THI thresholds is valuable for livestock management, empirical approaches cannot incorporate the whole range of factors that modify livestock susceptibility to increasing THI, such as geographic location, production system, breed, genotype, age, physiological and productive phase, acclimation state, presence and type of cooling systems, and management (Bernabucci et al., 2010; Nardone et al., 2010) or interactions between these variables. For ruminants, mechanistic modeling of thermal balances and heat stress needs to be linked to models of productivity and growth, and scaled up to herd level, taking account of variation in individual growth and performance. The impacts of rising temperatures on livestock need to be characterised in regional and global modeling, to better understand the economic consequences of climate change related heat stress at a broader scale (see Section 4). In addition, more modeling is needed to explore the impact of heat stress on livestock water requirements (Howden and Turnpenny, 1998), given that demand for water for crops is also likely to rise under climate change (Leclère et al., 2013), putting pressure on European water resources. There is a need to develop mechanistic models capable of identifying the most effective adaptation options in relation to heat stress 
(Lacetera et al., 2013) at farm- and policy-levels, from the exploration of genetic approaches (Collier and Gebremedhin, 2015) to systemic switches away from dairy cows towards more heat-tolerant livestock such as goats in southern Europe (Silanikove and Koluman, 2015).

\subsection{Modeling grassland productivity and nutritional value}

Climate change impacts on grasslands are expected to vary across Europe, with warmer temperatures and higher rainfall extending growing seasons in the north (Höglind et al., 2013) while the risk of drought is likely to increase in Mediterranean regions (van Oijen et al., 2014). Grassland productivity is known to be sensitive to temperature and water stress (Knapp et al., 2001) with impacts varying between different plant communities (Kreyling et al., 2008; Peterson et al., 1992).

Several types of model have been applied to grassland systems (Bellocchi et al., 2013); grassland-specific models (Kochy, 2008; Ma et al., 2015; Wu et al., 2007) models originally developed for crops and adapted to grasslands (Coucheney et al., 2015; Perego et al., 2013; Williams et al., 2008), and plant functional type-based models (Chang et al., 2013; Dury et al., 2011; Hidy et al., 2012; Waha et al., 2012). Previous modeling focussed on grassland productivity (Li et al., 2011; Woodward, 2001), mainly characterising monospecific swards or simple mixtures (Blackburn and Kothmann, 1989; Lazzarotto et al., 2009). Such models do not address the need for modeling of more diverse plant communities (Duru et al., 2009). Although functional classifications can simplify the characterisation of plant species (Cruz et al., 2002; Jouven et al., 2006) process-based biogeochemical models such as PaSim (Ma et al., 2015) usually use an average vegetation when simulating mixed swards, due to the challenges of modeling changes in botanical composition.

Although modeling of the impacts of climate change on yields from mono-specific grassland swards is well developed (Graux et al., 2013; Vital et al., 2013), fewer models assess the impacts of climate on nutritive value, which is vital with respect to animal production. Some models can simulate the development of nutritive value in timothy on cut swards (Bonesmo and Belanger, 2002; Jégo et al., 2013) and on pastures (Duru et al., 2010), and PaSim includes parameters relating to sward quality, including variation in digestibility with plant age and between plant components (Ben Touhami et al., 2013). However, in general the simulation of nutritive value is limited to species-specific responses, with little modeling of how interactions between species affect sward quality responses in multi-species grasslands. The characterisation of physiological and genetic adaptation of grassland species to changing conditions also requires more attention from modelers.

In addition to simulating the impacts of climate change in southern Europe, grassland models need to characterise changes in yield and nutritive value related to the expected prolongation of the growing season in northern and high altitude grasslands. Adding 'winter' modules to process-based models of grass growth offers one solution to this challenge. Such modules need to include the effects of changing winter conditions on sward growth (Höglind et al., 2013; Jégo et al., 2014; Jing et al., 2013) and to model the presence or absence of snow and the process of hardening and de-hardening, which is particularly important for Scandinavian grasslands (Höglind et al., 2010; Thorsen and Höglind, 2010a, b). Run-off of phosphorous from grasslands is also an issue of concern in the context of higher predicted rainfall in northern Europe. A number of models characterise phosphorous run-off (Benskin et al., 2014) but modeling of how this is affected by interactions between changing weather conditions and management choices needs to be improved.

To support grassland-based agriculture under climate change, grassland models require improved soil-water components, and need to be applicable to a wider range of species mixtures and management types. The capacity of models to predict the impacts of climate change on both yields and the nutritive value of forages needs to improve, in order to support policy choices and management decisions aimed at optimizing these parameters (Höglind and Bonesmo, 2002; Jégo et al., 2013; Jing et al., 2013). Lessons may be learnt from modeling developed for non-European semi-arid grazing lands, for example relating to the impact of grazing on erosion (Bénié et al., 2005). Integrated approaches including environmental and socio-economic aspects of grassland systems, such as the Sustainability and Organic Livestock Model (SOL) (FAO, 2012) demonstrate potential pathways for improving grassland modeling in the context of climate change.

\subsection{Modeling grassland biodiversity and interactions with productivity}

European grasslands are often hot-spots of biodiversity (Marriott et al., 2004) despite severe declines in species-rich grassland habitats driven by agricultural intensification and land abandonment (Henle et al., 2008). The development of the EU Biodiversity Strategy to 2020 exemplifies concern about the loss of biodiversity and related ecosystem services (Maes et al., 2012) highlighting the importance of models that characterise the effects of agricultural practices and climate change on grassland biodiversity (above and below ground and including plants, invertebrates, birds and mammals).

Decision Support System (DSS) models seek to predict the impacts of policies (and related changes in management practices) that target biodiversity conservation as an objective in itself. Recently, these have included approaches which bridge the gap between detailed models of specific sites and regional models that may overlook many important aspects of biodiversity (Johst et al., 2015; Mouysset et al., 2014). In such models, management information and knowledge of the ecological niches of different species or species groups are combined to predict the biodiversity impacts of different strategies, and the economic costs associated with achieving more favourable environmental outcomes (Johst et al., 2015; Mewes et al., 2015). Designed to characterise different management strategies and conditions, they could potentially be adapted to include the impacts of climate change on biodiversity (Johst et al., 2015; Mewes et al., 2015). Lee et al. (2010) addressed climate change related issues directly, combining empirical models with projections of future $\mathrm{CO}_{2}$ and nitrogen deposition to identify areas where grassland productivity may increase and biodiversity decrease.

Bio-economic optimisation models have also been applied to investigate how policy changes and subsequent management decisions could affect biodiversity (Mouysset et al., 2014; Schönhart et al., 2011). This can be achieved by including biodiversity as a target in multi-objective models, by assessing the impacts on biodiversity of choices made to meet other objectives, by including limits to biodiversity damage as constraints, or by including agrobiodiversity (such as mixed cropping) in management options (Allen et al., 2014). Nelson et al. (2009) used a spatially explicit model of land use change in Oregon (USA) to demonstrate a positive relationship between biodiversity and ecosystem services, and to show how a trade-off between these characteristics and commodity production could be alleviated using payments for carbon sequestration. This type of model can be applied to increase understanding of how management choices relating to climate change mitigation and adaptation impact biodiversity as well as productivity.

While the aforementioned models consider trade-offs between production and biodiversity treated as a goal in itself, biodiversity can also be viewed in terms of its contribution to productivity. This is the context in which (plant) biodiversity is considered in the grassland models described in Section 2.3. The positive relationship between biodiversity and a range of ecosystem services (Isbell et al., 2011; Oliver et al., 2015) provides a framework for a more 'holistic' quantification of the value of biodiversity, beyond its direct relationship with productivity. Modeling grassland biodiversity under different managements and environmental conditions requires a formalization of the role of mechanisms of plant species coexistence (Chesson, 2000), and their impacts on community structure (HilleRisLambers et al., 2012). Some mechanistic models of plant community dynamics include the explicit simulation of plant growth, development, and competition among species (Soussana et al., 2012b) including developmental plasticity in plant morphology arising from interaction with neighbours (Maire et al., 
2013). Studies of biodiversity in permanent grasslands have often focussed on this sub-plot scale, but do not consider how the landscape context affects biodiversity (Zobel, 2015). This would require comparative studies of local communities along broad-scale environmental gradients and in different biogeographic regions (Lessard et al., 2012). At this larger scale, detailed plant competition models are not feasible, being complex and difficult to initialize and parameterize. This explains the simplified treatment of these processes in larger scale models (see Section 2.3) achieved, for example, by identifying a main plant species and representing the others implicitly as a single competing species (Soussana et al., 2012b).

Principles have been developed for bridging the gap from smallscale mechanistic modeling to whole community approaches (Confalonieri, 2014), and there are opportunities to learn from modeling of crop systems (Balbi et al., 2015) and from techniques applied in other modeling disciplines. Tixier et al. (2013) consider the use of ecological network modeling approaches to enable multi-scale explorations of the impacts of environmental and management change on biodiversity and productivity. Examples include the use of linked crop and food web models to quantify feedbacks between crop management and pest-predator interactions, thus addressing trophic relationships which are often overlooked (Tixier et al., 2013).

The modeling of grassland biodiversity can help to capture important non-commodified benefits of livestock systems. Ignoring such benefits can lead to sub-optimal policy and management decisions (Meier et al., 2015). Given the pressure to increase agricultural production and efficiency under climate change, ensuring that biodiversity impacts are incorporated into models used to advise decision-makers is vital. To achieve this with an increasing level of sophistication will require new research and empirical data, particularly in poorly understood but highly important aspects of biodiversity, such as its role in soil dynamics (Lemaire et al., 2005). Modeling complex multi-scale agri-ecosystems can reveal hidden relationships and improve policy and management choices (Allen et al., 2014; Tixier et al., 2013). In the context of climate change, and its potential impacts on ecosystem services, this capability is essential.

\section{Modeling GHG emissions from ruminant systems}

\subsection{Farm-scale GHG emissions}

On-farm GHG emissions are most often modeled using the IPCC (2006) methodology, in which emissions factors are defined according to ascending levels of detail (Tiers 1,2 and 3). Tiers 1 and 2 use empirical emission factors, standardised across countries (Tier 1) or using countryspecific variables which better represent aspects of farming technology (Tier 2). Tier 3 models usually represent a change in approach from empirical to mechanistic modeling. For the construction of emission inventories, Tier 2 approaches are adequate, while for on-farm purposes the data demands of complex Tier 3 type models make simpler approaches more useable. However, the applicability of empirical Tier 1 and 2 approaches is limited by the data from which they were derived. For the estimation of emissions factors and how changes in management affect them, more detailed Tier 3 type modeling is required. The main on-farm sources of GHGs from ruminant production systems are emissions of $\mathrm{CH}_{4}$ from enteric fermentation and from manure, losses of $\mathrm{NO}_{3}, \mathrm{NH}_{3}$ and $\mathrm{N}_{2} \mathrm{O}$ from manure management and application, and from housing, and $\mathrm{N}_{2} \mathrm{O}$ emissions from grasslands and other soils (Gerber et al., 2013).

While Tier 2 approaches to predicting enteric $\mathrm{CH}_{4}$ emissions ignore digestive and fermentative processes, some models allow the assumption of a fixed $\mathrm{CH}_{4}$ emission per unit of gross energy intake to be replaced with predictions that vary with dietary characteristics such as digestibility (Graux et al., 2011) or diet composition (Schils et al., 2007). More mechanistic approaches including an integrated assessment of digestive and fermentative aspects of enteric $\mathrm{CH}_{4}$ emissions provide a more detailed analysis for a wider range of conditions (Bannink et al., 2011). Predictions may include effects on nitrogen utilisation and excreted nitrogen compounds as a source of GHG emissions (Dijkstra et al., 2011).

Since emissions from one link in the manure management chain (e.g. housing) reduce the source strength in subsequent links (e.g. storage), predicting responses to changes such as the implementation of mitigation strategies requires the use of models based on mass-conservation principles (Sommer et al., 2009).Current Tier 3 type modeling of $\mathrm{CH}_{4}$ emissions from manure incorporates the non-linear effects of management variables (type and quantity of organic matter inputs to the manure, manure storage type, duration and temperature) (Li et al., 2012; Sommer et al., 2009). However, although there are complex models of anaerobic slurry digestion (Batstone et al., 2002) - an important mitigation option (Weiske et al., 2006) - , it is not generally incorporated in farm-scale models.Modeling of this process at farm-scale should include the leakage of $\mathrm{CH}_{4}$ which can significantly reduce the offset of GHG emissions (Miranda et al., 2015). The main sources of $\mathrm{NH}_{3}$ emissions from manure management are animal housing, manure storage and applications to land. In addition to factors affecting $\mathrm{CH}_{4}$ emissions, $\mathrm{NH}_{3}$ emissions are dependent on the air temperature and ventilation of housing and the weather conditions during manure application. These factors can be mediated by management changes (e.g. acidification of slurry, anaerobic digestion, covering manure storage, and the use of injection equipment to apply slurry to land). The modeling method recommended in the Air Pollutant Emission Inventory Guidebook (EEA, 2013) improves on IPCC Tier 1 and 2 approaches by separately recognising housing as an $\mathrm{NH}_{3}$ emissions source. This makes it easier to assess the efficacy of mitigation options and to synthesize empirical data, as both often focus on individual emissions sources. Tier 3 approaches, such as that of Rotz et al. (2014) (based on the Integrated Farm System Model) enable a more nuanced investigation of the effect of manure management on $\mathrm{NH}_{3}$ emissions, which is particularly useful when assessing relative sensitivity to climatic variables and interactions with other pollutant emissions. Nutrients in manure originate primarily from animal excreta, so are affected by the quantity and quality of the feed ration. Estimating feed intake and quality for grazing animals remains a challenge for modeling $\mathrm{NH}_{3}$ emissions.

Mechanistic (Tier 3 type) models of $\mathrm{N}_{2} \mathrm{O}$ emissions from manure and soil (Li et al., 2012) are available, however, some aspects (such as parameterizing and predicting oxygen deficit in soil when require further improvement. $\mathrm{N}_{2} \mathrm{O}$ emissions also arise from leaching of $\mathrm{NO}_{3}$ from pastures, and this process has been modeled from the microcosm to the catchment-area scale (Cannavo et al., 2008). The approach of Cichota et al. (2013) tackles the complex spatial element of $\mathrm{NO}_{3}$ leaching from urine patches, but further efforts are needed to represent the effect of different management options on nitrogen dynamics, including interactions with soil variables and weather conditions.

Across all areas of GHG emissions modeling, better model characterisation of interactions between different components of ruminant systems are required, in order to meet the need for more robust, flexible farmscale modeling of strategies to mitigate GHG emissions and adapt to climate change. One example is the need to better incorporate the impacts of heat stress and animal disease (Sections 2.1 and 2.2) into farm-scale models of GHG emissions. More focus is required on the simultaneous modeling of the effect of management on carbon, nitrogen and phosphorus losses as exemplified by Ryals et al. (2015). This would allow the multiple pollutant cost effectiveness of mitigation measures to be assessed (Eory et al., 2013) (taking into account the impacts of mitigation measures targeting one GHG source on the emissions of other pollutants).

\subsection{Modeling carbon sequestration in grassland soils}

Grasslands managed for ruminant production store and sequester large amounts of carbon; in Europe, modeling studies have estimated that there are currently $5.5 \mathrm{Gt}$ of soil carbon stored in the top $30 \mathrm{~cm}$ of grassland soils (Lugato et al., 2014) giving grassland carbon sequestration a potentially major role in climate change mitigation (Glaesner et 
al., 2014). The importance of soil carbon to soil quality is also being recognised (Lugato et al., 2014) leading to increased interest in modeling the effect of agricultural management on soil carbon stocks. Modeling of this positive impact of grassland-based ruminant production is therefore vital to understanding the interactions between mitigation and adaptation strategies, to improving production efficiency, and to viewing farms in the context of 'Climate Smart Landscapes' (Scherr et al., 2012).

The IPCC (2006) have identified Tier 3 modeling as having the greatest potential for understanding the effect of agricultural management and climatic and soil conditions on soil carbon. These models could be applied to improve the current Marginal Abatement Cost Curve analyses used to identify cost-effective measures for reducing GHG emissions, which often make a range of assumptions in relation to soil carbon (Leip et al., 2010; Nayak et al., 2015). They may also provide uncertainties associated with mitigation strategies and their interaction with climatic factors, nitrogen cycles and management practices. Tier 3 models used range from those requiring the user to define the monthly input of plant residues, such as RothC (Coleman and Jenkinson, 1996) to those describing agricultural production in as much detail as soil processes, such as SPACSYS (Wu et al., 2007) and PaSim (Ma et al., 2015). There are also dynamic deterministic models of soil processes, such as DNDC (Li et al., 1992) and DailyDayCent (Parton et al., 1998), which represent crop growth using empirical functions. Many of the models can be applied to a range of plant species (Yagasaki and Shirato, 2013) and are typically verified at a small number of sites, where detailed data can be readily obtained (El-Maayar and Sonnentag, 2009; Yagasaki and Shirato, 2014).

One of the main objectives of soil carbon modeling is to assess the effects of management and climate change across management systems and pedo-climatic zones. For this purpose, Tier 3 models are currently being run at regional, national, continental and global scales (Gottschalk et al., 2012; Lugato et al., 2014). The DNDC model has also been coupled to CAPRI to provide predictions on soil carbon at the European scale (Britz and Leip, 2009). However, the analysis was limited by the emissions factor for carbon sequestration embedded in CAPRI, which assumes continual carbon sequestration by grasslands (Soussana et al., 2007, 2010).

The assumptions used in CAPRI highlight how differences in model design, and in the level of detail at which processes are characterised, will have an impact on the predictions produced. In order to understand the range of possible results predicted by models, ensemble modeling may be used (Robertson et al., 2015; Smith et al., 1997; van Oijen et al., 2014). However, to reduce differences in the outcomes of current modeling of carbon and nitrogen cycles, model algorithms and structure also need to be improved in order to better characterise physical and biophysical processes (Lu and Tian, 2013; Tian et al., 2011). Particular challenges surround the initialization of such models, including a lack of information about the initial state of carbon and nitrogen pools for particular sites (limited by measuring techniques and the detailed data and parameterisation required) (Hill, 2003) and the need to improve methods such as 'spin-up' simulations to overcome these practical limitations (Lardy et al., 2011). The sensitivity of soil carbon and nitrogen stocks and GHG emissions to climatic changes demands model based integrated assessment approaches ( Li et al., 1994). Properly validated process-based biogeochemical models incorporating coupled carbon-nitrogen cycling can be effective tools for examining the magnitude and spatial-temporal patterns of carbon and nitrogen fluxes. However, the development and testing of such models will require more effective collection, collation and sharing of high quality experimental data (del Prado et al., 2013; Smith et al., 2002).

\subsection{Environmental impacts beyond the farm}

The impacts of livestock production extends far beyond the farm, including local impacts on surrounding ecosystems and wider impacts related to the production and transport of purchased inputs. The modeling of on-farm emissions supports the identification of mitigation strategies that are efficient at farm level. However, approaches (such as IPCC methodologies) which do not take into account off-farm environmental impacts, can risk favouring systems and strategies that transfer emissions to other locations, rather than reducing them (O'Brien et al., 2012). The Global livestock environmental assessment model (GLEAM) applies a static process-based modeling approach to assess GHG emissions associated with meat and dairy products, incorporating both on- and off-farm emission sources (Opio et al., 2013). GLEAM uses Tier 2 equations and regional scale data to capture the impacts of varying local conditions not revealed by global or national average data (FAO, 2016). Models such as GLEAM that integrate simulation modeling and Life Cycle analysis (LCA) approaches, offer modeling solutions that make environmental sense at the global as well as the local scale (de Boer et al., 2011). The development of more holistic LCA methodologies (Bruckner et al., 2015; Huysveld et al., 2015) and the exploration of new LCA applications, for example as a farm decision support (DSS) tool (Meul et al., 2014) may present further opportunities to combine farm-scale modeling and LCA approaches. Farm-scale modelers share many of the challenges recognised in LCA, such as the need to increase standards and consistency of data and assumptions (Eshel et al., 2015) and to ensure that users correctly interpret the outcomes of studies (Cederberg et al., 2013; Meul et al., 2014).

\section{Regional and global economic modeling of livestock systems}

The development of economic models of livestock systems, including modules that balance and optimise animal diets in terms of cost, has been driven by the high share of livestock products in EU agricultural outputs, with animal production accounting for $42 \%$ of EU-28 agricultural output (Marquer et al., 2014), as well as by the high cost of feed. At global and regional level, models of agriculture and trade are used to explore how livestock production may alter in response to the impacts of climate change on the economics of production (Audsley et al., 2015; Havlík et al., 2014). This may include the effects of technological change, population growth (Schneider et al., 2011), the consequences of various assumptions about land availability (Schmitz et al., 2014), and the impact of changes in human diet (Bajzelj et al., 2014). Modeling is also used to explore the regional and global consequences of different approaches to climate change mitigation, in order to identify optimal solutions (Havlík et al., 2014).

Results from recent modeling of European agriculture suggest that socio-economic factors will have a greater impact than climate change on land use, production systems and their outputs (Audsley et al., 2006; Leclère et al., 2013). However, with respect to ruminant production systems, most regional and global models only take into account indirect climate change impacts, arising from changes in crop yields and prices. Aspects not currently addressed include, the effects of increased and extreme temperatures on livestock health and production, changes in pathogen spread and abundance, changes in grassland yield, changes in crop and grassland nutritional quality, competition for water resources and the impact of adaptation strategies (from animal genetics to changing management choices). Work in these areas is developing; Chang et al. (2015) modeled changes in European grassland productivity between 1961 and 2010, while Schönhart and Nadeem (2015) used empirical relationships between THI and animal health to estimate the costs of climate change impacts on dairy cow productivity in Austria. Other aspects, such as the non-commodified benefits of ruminant systems (Section 2.4) are often overlooked. Policies affect individual farmers and their choices, making exploration of the impacts of farmlevel decisions valuable for the assessment of policy and mitigation strategies (Eory et al., 2014). Leclère et al. (2013) demonstrated how autonomous farm-scale decision making could be incorporated into regional modeling. However, their characterisation of livestock systems focussed only on impacts of climate change stemming from changes in crop prices and yield. Achieving a fuller representation of livestock systems in regional and global economic modeling, by increasing the 
number of variables considered, and by strengthening the basis of assumptions, should therefore be a priority.

In the context of the previous discussion, modeling of climate change impacts on livestock production still remains highly uncertain. Developing a range of consistent future scenarios would improve model comparability, and might allow more factors to be incorporated into modeling. The development of such scenarios has begun (Antle et al., 2015) however, comparisons of global economic models within the Agricultural Model Intercomparison and Improvement Project (AgMIP) (http://www.agmip.org) (von Lampe et al., 2014) revealed wide inter-model variation in predictions even when models used identical future scenarios (Nelson et al., 2014; Valin et al., 2014). Although the uncertainty in such predictions is normal in the field of economics, it is great compared to that usually encountered in the natural sciences. The problem of modeling uncertainty has been tackled in climate and crop modeling using model ensembles (Martre et al., 2015) but for economic modeling, other improvements are needed before this approach can be considered. Models developed to make predictions about relatively stable economic environments need to be evaluated to understand if they are adequate for characterising the periods of high socioeconomic uncertainty expected to accompany climate change, including developing a better understanding of the parameters driving empirically modeled relationships. Improved transparency and sharing of methods is required for such model evaluation and improvement to be effective. In addition to improving existing regional scale economic models, new models are needed to adequately analyse complex dynamic processes and uncertainty; dynamic stochastic general equilibrium models, which could be useful in this context, are so far only applied to financial market analyses.

\section{Stakeholders and modeling}

Engagement between agricultural stakeholders and modelers has long been recognised as vital to developing models that can support effective farm- and policy-level decision making (Voinov and Bousquet,
2010), with engagement processes involving the development of modeling tools (participatory modeling) or the application of existing models to solve a problem. Different approaches to stakeholder engagement in the context of agricultural systems have been defined (Colvin et al., 2014; Neef and Neubert, 2011). Martin et al. (2013) identified two types of approach to farm system design initiatives that make use of modeling: 1) optimisation approaches and 2) participation and simulation-based approaches. These types of stakeholder engagement are consistent with descriptions of 'hard' and 'soft' system approaches (Matthews et al., 2011; van Paassen et al., 2007). Optimisation or hard system approaches are positivist; the problem to be addressed is quickly identified and is not contested, system boundaries are identified, and scientific data are used to generate a range of solutions, using modeling tools to explore these options (Martin et al., 2013). Stakeholders are engaged most in the process of understanding system parameters, processes and inputs and outputs, but rarely in defining the problem or evaluating solutions. In contrast, participatory or 'soft' system approaches emphasise the need to explore stakeholder perceptions in order to identify problems and potential solutions, in a process of collaborative or collegiate engagement. This goes beyond the contractual and consultative levels of participation (Barreteau et al., 2010) more common in optimisation approaches. Processes are based on mutual learning, from which solutions can emerge through iterative and reflective relationships between stakeholders and researchers (Colvin et al., 2014; Martin et al., 2013). This reflects the fact that, in addition to being learning tools, models can play an important role in creating a community from disparate groups of stakeholders, and in putting issues onto the political agenda (Sterk et al., 2011). In a wider context, these categories relate to the knowledge production practices identified by Rodela et al. (2012) which range from 'positivist truth-seeking' (in which the scientist has the role of a neutral outsider) to 'post-normal searches for negotiated agreement' (in which the scientist is an advocate and participant in the process).

Challenges for participatory approaches include the time and effort required by stakeholders and researchers to engage fully in mutual

Table 1

Areas of ruminant systems modeling covered in this paper, their current applications and broad challenges for improvement in relation to climate change.

\begin{tabular}{|c|c|c|}
\hline Modeling topic & Current applications & Some broad challenges \\
\hline $\begin{array}{l}\text { Farm-scale } \\
\text { emissions }\end{array}$ & $\begin{array}{l}\text { DSS at farm level, contributions to national emissions inventories, assessing } \\
\text { impacts of policy }\end{array}$ & $\begin{array}{l}\text { Need for more Tier } 3 \text { type modeling to improve understanding of systemic } \\
\text { interactions, to validate empirical (Tier } 1 \& 2 \text { type) relationships and to } \\
\text { incorporate adaptation and mitigation strategies and impacts of impaired } \\
\text { animal health }\end{array}$ \\
\hline $\begin{array}{l}\text { Carbon } \\
\text { sequestration }\end{array}$ & $\begin{array}{l}\text { Contributions to inventories of carbon stocks, policy level predictions of } \\
\text { variation with climate \& changes in land use }\end{array}$ & $\begin{array}{l}\text { Improved data collation and sharing, facilitating more mechanistic (Tier } 3 \\
\text { type) modeling of the impacts of climate change, land use change and } \\
\text { adaptation and mitigation options }\end{array}$ \\
\hline LCA & Providing evidence to guide policy level and on-farm choices & $\begin{array}{l}\text { Linking to farm-scale modeling to incorporate wider environmental impacts } \\
\text { into farm-scale environmental and economic assessments; standardising } \\
\text { assumptions and data }\end{array}$ \\
\hline Heat Stress & $\begin{array}{l}\text { DSS at farm level to support avoidance/control of heat stress, estimates of } \\
\text { impacts of increased THI on production \& reproduction }\end{array}$ & $\begin{array}{l}\text { Need for more mechanistic modeling of heat stress and its impacts under } \\
\text { climate change, incorporation of the variables affecting stress, and of } \\
\text { adaptation and mitigation strategies }\end{array}$ \\
\hline Pathogens & $\begin{array}{l}\text { DSS at farm level, estimates of impacts on productivity, policy support (risks } \\
\text { of spread for specific pathogens and vectors), assessing impacts of policy }\end{array}$ & $\begin{array}{l}\text { Improved data on pathogen ecology and spread to facilitate more mechanistic } \\
\text { modeling of future impacts under climate change, outbreak intensity and } \\
\text { management responses }\end{array}$ \\
\hline Grasslands & $\begin{array}{l}\text { DSS at farm level, projections of yield change under future climates at the } \\
\text { regional scale }\end{array}$ & $\begin{array}{l}\text { Modeling of climate change impact on grass quality, modeling multi-species } \\
\text { swards, modeling impact of adaptation and mitigation strategies }\end{array}$ \\
\hline $\begin{array}{c}\text { Biodiversity \& } \\
\text { ecosystems }\end{array}$ & $\begin{array}{l}\text { DSS at farm level, bio-economic optimisation models including biodiversity } \\
\text { constraints/goals, links to ecosystem services and regional impacts of policy }\end{array}$ & $\begin{array}{l}\text { Developing linkages to agricultural models to facilitate multi-species } \\
\text { modeling and to include the non-commodified value of ruminant systems in } \\
\text { environmental/economic evaluations }\end{array}$ \\
\hline $\begin{array}{l}\text { Regional } \\
\text { economics }\end{array}$ & $\begin{array}{l}\text { Policy level assessments of economic impacts of climate change on livestock } \\
\text { agriculture, based on changes in crop yield and price, including changes in } \\
\text { livestock systems land use }\end{array}$ & $\begin{array}{l}\text { Incorporating impacts of climate change on ruminant systems beyond } \\
\text { changes in feed prices/yield (e.g. impact of heat stress, increased water use, } \\
\text { increased disease risk, potential changes in soil carbon storage). Including } \\
\text { non-commodified benefits from these systems }\end{array}$ \\
\hline $\begin{array}{l}\text { Stakeholder } \\
\text { engagement }\end{array}$ & $\begin{array}{l}\text { Defining modeling scenarios and priorities (including climate change impacts } \\
\text { and relevance of modeled adaptation and mitigation strategies), use of } \\
\text { models for learning, community building and highlighting issues at policy } \\
\text { level (Sterk et al. 2011) }\end{array}$ & $\begin{array}{l}\text { Finding approaches that overcome issues relating to the time taken for } \\
\text { engagement (researchers and stakeholders), scaling up lessons learnt in } \\
\text { specific case studies to policy level, finding ways to incorporate qualitative } \\
\text { values communicated by stakeholders (including the public) into modeling, } \\
\text { such as the social value of biodiverse landscapes }\end{array}$ \\
\hline
\end{tabular}


learning, which can lead to 'participation fatigue' (Neef and Neubert, 2011) and the difficulty of generalising from tailor-made solutions to inform policy level decision making at a larger scale (Colvin et al., 2014). Van Latesteijn (1999) illustrated the challenge of relating small-scale, deep scientific findings to the large scale, wide and shallow outlook of policymakers, with scientists required to present more simple and convincing 'facts' about the future. Another challenges is that processes including stakeholders often arrive at 'exploitative innovation' solutions, which use existing knowledge to adjust current systems, rather than 'explorative innovation' solutions that facilitate novel changes (Martin et al., 2013). The bottom-up way in which explorative innovations emerge can challenge existing frameworks, and as a result may face institutional barriers to implementation (Colvin et al., 2014). However, these types of innovation are important in adapting agricultural production systems to climate change conditions (Martin et al., 2013).

In order to develop and best utilise modeling tools to support farmand policy-level decision-making in the context of climate change, it will be essential for modelers to work with social scientists to identify and apply effective approaches to stakeholder engagement, integrating many knowledge forms and perspective (Rodela et al., 2012).If existing models are to be available for application to real-world problems, they need to be open to modification, 'tested, wrapped, documented and archived' (Voinov and Bousquet, 2010). A range of recent work contributes to building the modeling capacity required to support effective decision making in relation to climate change adaptation and mitigation in livestock production systems. This includes, successful trans-disciplinary approaches to supporting agricultural systems vulnerable to climate change (van Paassen et al., 2007) and deliberative approaches to model evaluation (Bellocchi et al., 2015).

\section{Synthesis}

The preceding sections demonstrate the richness and complexity of modeling relating to European ruminant production systems, with models applied at all scales to support stakeholders facing the challenges of climate change (Table 1). Ruminant systems are multi-faceted, with each component interacting with others, and (singly and as part of the wider systemic whole) interacting with other biophysical, economic and social systems and processes. A number of broad challenges to the modeling of ruminant systems in the context of climate change have been identified here (Table 1 ).

One major challenge for ruminant systems modeling is that regional and global scale models often overlook the direct impacts of climate change on such systems. This is of concern given the role of ruminant systems in the provision of ecosystem services and other social benefits (Section 2.4), and due to the interactions between livestock agriculture and other systems. The development of socio-economic scenarios representing consistent, realistic suites of management and policy choices 'packaged' at regional level (Valdivia et al., 2013) offers a path for better incorporating understanding of farm- and policy-level decision making into models, and for giving weight to the "non-commodified' value of ruminant systems. At the same time, empirical representations of biophysical processes and interactions in regional and global models can be evaluated and improved using knowledge gained from mechanistic modeling at field, animal and farm-scales. In this respect, complex and simple modeling approaches can be seen not in opposition, but as part of an iterative process of model development (Fig. 2) applicable to all levels of modeling, not just the regional level. This can allow the development of 'smart' empirical modules which reduce model complexity in a robust manner, rather than through the use of assumptions to fill gaps in knowledge.

The purpose of modeling is not to fully represent every aspect of real world systems (Cederberg et al., 2013); models will always incorporate simplification and uncertainty. Rather, their value is in providing an understanding of complex systems, predicting change in such systems, and revealing systemic relationships that would otherwise be hidden (van Paassen et al., 2007). Modelers need to clearly present and explain model outputs, their meaning and limitations. In turn, decision-makers (particularly at policy level) need to develop a sufficiently good understanding of the real world systems with which they are dealing for them to use model outputs and other evidential sources appropriately. In this context, the interpretation of modeling results becomes a joint concern of modelers and the users of model outputs.

Engaging with stakeholders at all stages of research, including in the definition of problems, is likely to increase the chances that model outputs and their strengths and weaknesses will be understood at a deep rather than superficial level (Voinov and Bousquet, 2010). Through such engagement, the required level of model complexity, accuracy and scope can emerge from deliberative processes (Bellocchi et al.,
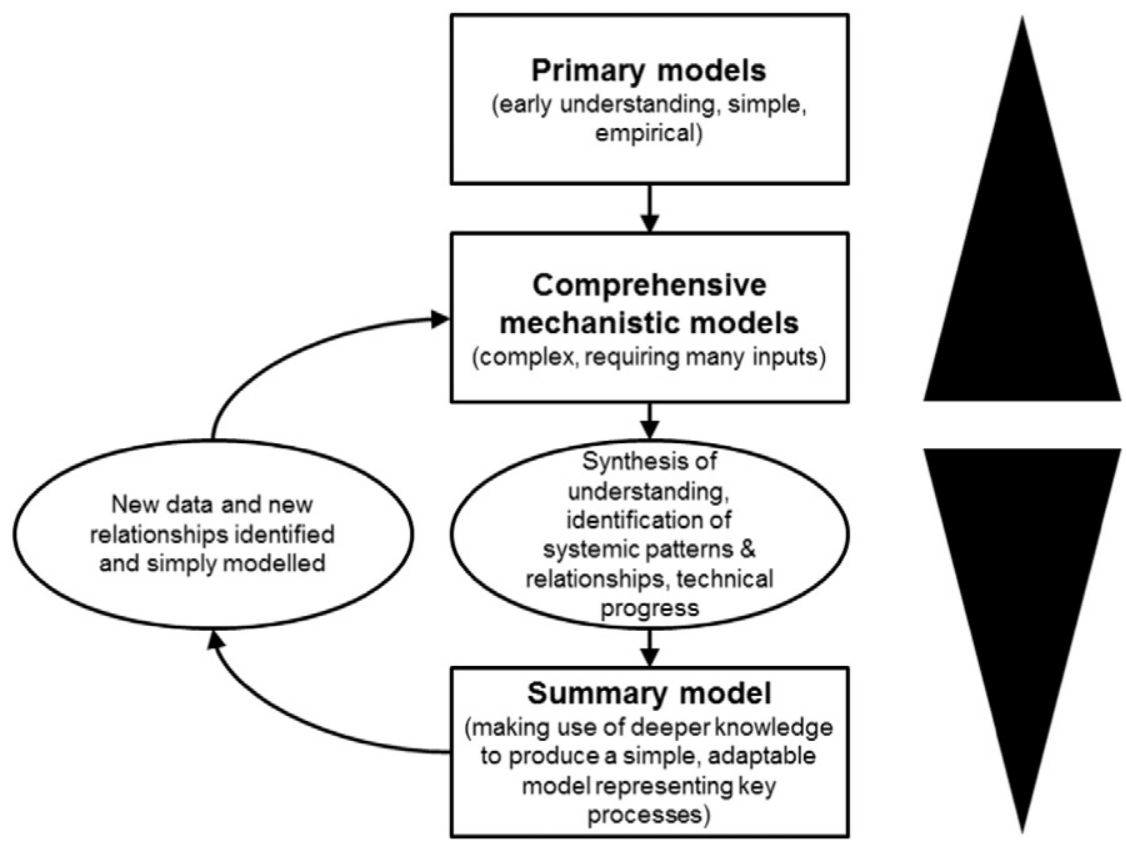

Fig. 2. How the simple-complex model problem can be re-framed as an iterative development process. Black triangles represent the level of model complexity. 
2015; Colvin et al., 2014). In this respect, individuals with knowledge of both the research and stakeholder communities can act as 'bridges' between different groups (Sterk et al., 2011). Social scientists are often well placed to fulfil this role, promoting and guiding mutual learning and facilitating the achievement of positive outcomes (Colvin et al., 2014). The challenge for modelers is to use the process described to create models that are both 'user friendly' and robust at appropriate levels of complexity.

The disparate nature of modeling relating to ruminant systems, demonstrated in this paper, means that there are many barriers to achieving the types of collaborative interaction between modelers required to meet the challenge of climate change. Technical issues related to linking models are one major obstacle to more joined-up modeling of ruminant systems. The development of modeling platforms supporting modular approaches and utilising compatible software and coding, can help build capacity within a highly adaptive framework (Holzworth et al., 2015). Such systems can also facilitate the exchange of methods and information between modeling fields and between groups within a field, stimulate the spread of best practice, prevent duplication, and increase model comparability. Strategic modeling platforms can also play a valuable role in providing policy level advice. Livestock modelers can look towards initiatives set up in relation to crop systems, such as MARS (Monitoring Agricultural ResourceS) (https://ec.europa.eu/jrc/ en/mars), for examples of what is required to communicate model predictions at the European level.

Developing models of ruminant farming systems can take years, while major decisions relating to GHG mitigation and the adaptation of livestock systems to climate change are required urgently. Therefore, in addition to developing new modeling, it is important that best use is made of existing data and models, ensuring that knowledge gained and tools developed are made available to decision-makers at a range of scales. In this context, researchers and funders need to support the development of data sharing resources such as those within the Global Research Alliance (GRA) (http://globalresearchalliance.org) (Yeluripati et al., 2015) and in projects such as the EU knowledge hub Modeling European Agriculture for Food Security under Climate Change (MACSUR) (http://macsur.eu). As technological capacity for data sharing and data processing grows, it also needs to be matched by the development of better communication between modelers and experimental and theoretical researchers. Such connections support modelers by facilitating model development, but also benefit data providers, by providing a path to demonstrate and explore the implications of their findings and to indicate areas for future research. The development of networks that bring together the disparate collection of disciplines relevant to livestock systems modeling is therefore essential, both for the sharing of current data and modeling resources, and for the development of new modeling platforms. Barriers to inter-disciplinary working (Siedlok and Hibbert, 2014) mean that creating structures to build modeling capacity and share knowledge across disciplinary boundaries requires carefully considered, coherent and long-term support from funders and policymakers.

This paper has attempted 1 ) to provide an overview of how current ruminant production systems modeling supports the efforts of stakeholders and policymakers to predict, mitigate, and adapt to climate change and 2) to provide ideas about how modeling resources can be enhanced to best meet these challenges. More focussed assessments of specific modeling fields and the priorities for their development, would be useful in shaping priorities for future research in the context of climate change.

\section{Future perspectives}

The overview of European ruminant system modeling presented provides pointers towards the future development required across modeling disciplines, in order to meet the challenges of climate change. Unfolding challenges for modelers in a climate change world include 1) better characterisation of adaptation strategies and complex biophysical processes, 2) more modeling of interactions between the diverse components of agro-ecosystems (including management strategies addressing different policy targets) and 3) better linkage between animal health and disease, animal growth and nutrition, crop and grassland and farm- and regional-scale modelers. Four key areas need to be addressed if the potential for agricultural modeling to help tackle the challenges of climate change is to be properly exploited:

- Making modeling more relevant to real-world problems by increasing the accessibility, visibility and comparability of models for different uses, and by engaging with stakeholders at all stages in modeling research and development.

- Developing modeling capacity through mutual learning and increased technical compatibility across modeling disciplines, and between modelers working at different scales.

- Fostering better links between modelers and empirical researchers to ensure that high quality data and research findings can be easily accessed by modelers, and that modeling outputs can more effectively inform the focus of new experimental and theoretical research.

- Ensuring that modeling outputs, their strengths, limitations and purpose are understood by those that use them, recognising that achieving this will require the commitment of time and resources by both modelers and stakeholders, including policymakers.

Within Europe and beyond, achieving progression in these areas is an undertaking that will require coherent long-term support from funders, policymakers, and academics across the plethora of organisations involved in the creation of inter-disciplinary research structures. Modeling can offer vital insights into the complex interacting relationships between climate change, management and policy choices, food production and the maintenance of vital ecosystem services. Modelers, empirical researchers and social scientists need to work together across disciplines, in collaboration with stakeholders, to develop and make effective use of this potential.

\section{Conclusion}

A continuing stream of papers has been published on agricultural modeling over recent years, with research supported by a range of global initiatives. However, the inherent complexity associated with ruminant system modeling has meant that it has been less developed than other areas such as crop modeling. In this context, the aim here has been to provide an overview of ruminant systems modeling in Europe. Modeling of ruminant production is currently supporting on-farm decisions to minimise GHG emissions and maximise efficiency, helping to assess and evaluate policy choices in the context of climate change, and developing our understanding of the likely impacts of global warming on European food production. It is hoped that the synthesis of modeling presented here will help strengthen the basis for constructive and strategic engagement between the European modeling community, non-European modelers and experimental researchers, through initiatives such as MACSUR, AgMIP and GRA.

\section{Acknowledgements}

This paper was produced through the international research project FACCE MACSUR - Modeling European Agriculture with Climate Change for Food Security - a FACCE JPI knowledge hub; the work was supported at national level by BBSRC, NERC and Scottish Government (UK), BMLFUW (Austria), EL\&I (The Netherlands), the metaprogramme Adaptation of Agriculture and Forests to Climate Change (AAFCC) of INRA (France), MIPAAF (Italy), MMM (Finland), Ministry of Science, Technology and Innovation (Denmark). 


\section{References}

Allen, T., Prosperi, P., Cogill, B., Flichman, G., 2014. Agricultural biodiversity, social-ecological systems and sustainable diets. Proc. Nutr. Soc. 73, 498-508. http://dx.doi.org/10. 1017/S002966511400069X.

Antle, J.M., Valdivia, R.O., Boote, K.J., Janssen, S., Jones, J.W., Porter, C.H., Rosenzweig, C., Ruane, A.C., Thorburn, P.J., 2015. AgMIP's transdisciplinary agricultural systems approach to regional integrated assessment of climate impacts, vulnerability, and adaptation. In: Rosenzweig, C., Hills, D. (Eds.), Handbook of Climate Change and Agroecosystems. Imperial College Press, London.

ATF, 2013. Research and Innovation for a Sustainable Livestock Sector in Europe: Suggested Priorities for Support under Horizon 2020 to Enhance Innovation and Sustainability in the Animal Production Sector of Europe's Food Supply Chains, Animal Task Force White Paper.

ATF, 2014. Research and Innovation for a Competitive and Sustainable Animal Production Sector in Europe: Recommended Priorities for Support Under Horizon 2020 in the 2016/2017 Programme, 1st Addendum to the Animal Task Force White Paper.

Audsley, E., Pearn, K.R., Simota, C., Cojocaru, G., Koutsidou, E., Rounsevell, M.D.A., Trnka, M., Alexandrov, V., 2006. What can scenario modelling tell us about future European scale agricultural land use, and what not? Environ. Sci. Pol. 9, 148-162. http://dx.doi. org/10.1016/j.envsci.2005.11.008.

Audsley, E., Trnka, M., Sabaté, S., Maspons, J., Sanchez, A., Sandars, D., Balek, J., Pearn, K. 2015. Interactively modelling land profitability to estimate European agricultural and forest land use under future scenarios of climate, socio-economics and adaptation. Clim. Chang. 128, 215-227. http://dx.doi.org/10.1007/s10584-014-1164-6.

Bajzelj, B., Richards, K.S., Allwood, J.M., Smith, P., Dennis, J.S., Curmi, E., Gilligan, C.A., 2014 Importance of food-demand management for climate mitigation. Nat. Clim. Chang. 4, 924-929. http://dx.doi.org/10.1038/nclimate2353.

Balbi, S., Prado, A.d., Gallejones, P., Geevan, C.P., Pardo, G., Pérez-Miñana, E., Manrique, R., Hernandez-Santiago, C., Villa, F., 2015. Modeling trade-offs among ecosystem services in agricultural production systems. Environ. Model. Softw. 72, 314-326. http://dx.doi. org/10.1016/j.envsoft.2014.12.017.

Bannink, A., van Schijndel, M.W., Dijkstra, J., 2011. A model of enteric fermentation in dairy cows to estimate methane emission for the Dutch national inventory report using the IPCC tier 3 approach. Anim. Feed Sci. Technol. 166-167, 603-618. http:// dx.doi.org/10.1016/j.anifeedsci.2011.04.043.

Barreteau, O., Bots, P., Daniell, K., 2010. A framework for clarifying participation in participatory research to prevent its rejection for the wrong reasons. Ecol. Soc. 15 (22 pp.).

Batstone, D.J., Keller, J., Angelidaki, I., Kalyuzhnyi, S.V., Pavlostathis, S.G., Rozzi, A., Sanders, W.T.M., Siegrist, H., Vavilin, V.A., 2002. The IWA anaerobic digestion model no 1 (ADM1). Water Sci. Technol. 45, 65-73.

Bellocchi, G., Ma, S., Köchy, M., Braunmiller, K., 2013. Identified grassland-livestock production systems and related models. FACCE MACSUR Reports 2, D-L2.1.1.

Bellocchi, G., Rivington, M., Matthews, K., Acutis, M., 2015. Deliberative processes for comprehensive evaluation of agroecological models. A review. Agron. Sustain. Dev. 35, 589-605. http://dx.doi.org/10.1007/s13593-014-0271-0.

Ben Touhami, H., Lardy, R., Barra, V., Bellocchi, G., 2013. Screening parameters in the pasture simulation model using the Morris method. Ecol. Model. 266, 42-57. http://dx. doi.org/10.1016/j.ecolmodel.2013.07.005.

Bénié, G.B., Goïta, K., Kabore, S.S., Courel, M.F., 2005. Remote sensing-based spatio-temporal modeling to predict biomass in Sahelian grazing ecosystem. Ecol. Model. 184, 341-354. http://dx.doi.org/10.1016/j.ecolmodel.2004.10.012.

Benskin, C.M.H., Roberts, W.M., Wang, Y., Haygarth, P.M., 2014. Review of the annual phosphorus loss estimator tool - a new model for estimating phosphorus losses at the field scale. Soil Use Manag. 30, 337-341. http://dx.doi.org/10.1111/sum.12128.

Bernabucci, U., Lacetera, N., Baumgard, L.H., Rhoads, R.P., Ronchi, B., Nardone, A., 2010. Metabolic and hormonal acclimation to heat stress in domesticated ruminants. Animal 4, 1167-1183. http://dx.doi.org/10.1017/s175173111000090x.

Bertocchi, L., Vitali, A., Lacetera, N., Nardone, A., Varisco, G., Bernabucci, U., 2014. Seasonal variations in the composition of Holstein cow's milk and temperature-humidity index relationship. Animal 8, 667-674. http://dx.doi.org/10.1017/s1751731114000032.

Blackburn, H.D., Kothmann, M.M., 1989. A forage dynamics model for use in range or pasture environments. Grass Forage Sci. 44, 283-294. http://dx.doi.org/10.1111/j.13652494.1989.tb02166.x.

Bohmanova, J., Misztal, I., Cole, J.B., 2007. Temperature-humidity indices as indicators of milk production losses due to heat stress. J. Dairy Sci. 90, 1947-1956. http://dx.doi. org/10.3168/jds.2006-513.

Bonesmo, H., Belanger, G., 2002. Timothy yield and nutritive value by the CATIMO model: II. Digestibility and fiber. Agron. J. 94, 345-350.

Britz, W., Leip, A., 2009. Development of marginal emission factors for $\mathrm{N}$ losses from agricultural soils with the DNDC-CAPRI meta-model. Agric. Ecosyst. Environ. 133, 267-279. http://dx.doi.org/10.1016/j.agee.2009.04.026.

Broughan, J.M., Wall, R., 2007. Fly abundance and climate as determinants of sheep blowfly strike incidence in southwest England. Med. Vet. Entomol. 21, 231-238. http://dx. doi.org/10.1111/j.1365-2915.2007.00689.x.

Bruckner, M., Fischer, G., Tramberend, S., Giljum, S., 2015. Measuring telecouplings in the global land system: a review and comparative evaluation of land footprint accounting methods. Ecol. Econ. 114, 11-21. http://dx.doi.org/10.1016/j.ecolecon.2015.03.008.

Cannavo, P., Recous, S., Parnaudeau, V., Reau, R., 2008. Modeling N dynamics to assess environmental impacts of cropped soils. Adv. Agron. 97, 131-174. http://dx.doi.org/10 1016/S0065-2113(07)00004-1.

Cederberg, C., Henriksson, M., Berglund, M., 2013. An LCA researcher's wish list - data and emission models needed to improve LCA studies of animal production. Animal 7, 212-219. http://dx.doi.org/10.1017/S1751731113000785.

Chang, J.F., Viovy, N., Vuichard, N., Ciais, P., Wang, T., Cozic, A., Lardy, R., Graux, A.I., Klumpp, K., Martin, R., Soussana, J.F., 2013. Incorporating grassland management in
ORCHIDEE: model description and evaluation at 11 eddy-covariance sites in Europe. Geosci. Model Dev. 6, 2165-2181. http://dx.doi.org/10.5194/gmd-6-2165-2013.

Chang, J., Viovy, N., Vuichard, N., Ciais, P., Campioli, M., Klumpp, K., Martin, R., Leip, A. Soussana, J.-F., 2015. Modeled changes in potential grassland productivity and in grass-fed ruminant livestock density in Europe over 1961-2010. PLoS ONE 10, e0127554. http://dx.doi.org/10.1371/journal.pone.0127554.

Chaparro, M.A.E., Canziani, G.A., Saumell, C.A., Fiel, C.A., 2011. Estimation of pasture infectivity according to weather conditions through a fuzzy parametrized model for the free-living stage of Ostertagia ostertagi. Ecol. Model. 222, 1820-1832. http://dx.doi. org/10.1016/j.ecolmodel.2011.03.019.

Chesson, P., 2000. Mechanisms of maintenance of species diversity. Annu. Rev. Ecol. Syst. 31, 343-366.

Cichota, R., Snow, V.O., Vogeler, I., 2013. Modelling nitrogen leaching from overlapping urine patches. Environ. Model. Softw. 41, 15-26. http://dx.doi.org/10.1016/j.envsoft. 2012.10.011.

Coleman, K., Jenkinson, D., 1996. RothC-26.3 - a model for the turnover of carbon in soil In: Powlson, D.S., Smith, J.U., Smith, P. (Eds.), Evaluation of Soil Organic Matter Models Using Existing Long Term Data-Sets. Springer-Verlag, Heidelberg.

Collier, R.J., Gebremedhin, K.G., 2015. Thermal biology of domestic animals. Annu. Rev. Anim. Biosci. 3, 513-532. http://dx.doi.org/10.1146/annurev-animal-022114110659.

Colvin, J., Blackmore, C., Chimbuya, S., Collins, K., Dent, M., Goss, J., Ison, R., Roggero, P.P., Seddaiu, G., 2014. In search of systemic innovation for sustainable development: a design praxis emerging from a decade of social learning inquiry. Res. Policy 43, 760-771. http://dx.doi.org/10.1016/j.respol.2013.12.010.

Confalonieri, R., 2014. CoSMo: a simple approach for reproducing plant community dynamics using a single instance of generic crop simulators. Ecol. Model. 286, 1-10. http://dx.doi.org/10.1016/j.ecolmodel.2014.04.019.

Coucheney, E., Buis, S., Launay, M., Constantin, J., Mary, B., García de Cortázar-Atauri, I., Ripoche, D., Beaudoin, N., Ruget, F., Andrianarisoa, K.S., Le Bas, C., Justes, E., Léonard, J., 2015. Accuracy, Robustness and Behavior of the STICS Soil-Crop Model for Plant Water and Nitrogen Outputs: Evaluation Over a Wide range of Agro-Environmental Conditions in France. 64 pp. 177-190. http://dx.doi.org/10.1016/j.envsoft.2014.11.024.

Cruz, P., Therond, O., Theau, J.P., Ducourtieux, C., Jouany, C., Al Haj Kamhed, R., Ansquer, P., 2002. Une nouvelle approche pour caractériser les prairies naturelles et leur valeur d'usage. Fourrages 172, 335-354.

Davis, S.J., Caldeira, K., 2010. Consumption-based accounting of $\mathrm{CO}_{2}$ emissions. Proc. Natl. Acad. Sci. 107, 5687-5692. http://dx.doi.org/10.1073/pnas.0906974107.

de Boer, I.J.M., Cederberg, C., Eady, S., Gollnow, S., Kristensen, T., Macleod, M., Meul, M. Nemecek, T., Phong, L.T., Thoma, G., van der Werf, H.M.G., Williams, A.G. Zonderland-Thomassen, M.A., 2011. Greenhouse gas mitigation in animal production: towards an integrated life cycle sustainability assessment. Curr. Opin. Environ. Sustain. 3, 423-431. http://dx.doi.org/10.1016/j.cosust.2011.08.007.

de Rensis, F., Garcia-Ispierto, I., López-Gatius, F., 2015. Seasonal heat stress: clinical implications and hormone treatments for the fertility of dairy cows. Theriogenology 84 659-666. http://dx.doi.org/10.1016/j.theriogenology.2015.04.021.

del Prado, A., Crosson, P., Olesen, J.E., Rotz, C.A., 2013. Whole-farm models to quantify greenhouse gas emissions and their potential use for linking climate change mitigation and adaptation in temperate grassland ruminant-based farming systems. Animal 7. 373-385. http://dx.doi.org/10.1017/S1751731113000748.

Dijkstra, J., France, J., Ellis, J.L., Kebreab, E., López, S., Reijs, J.W., Bannink, A., 2011. Effects of nutritional strategies on simulated nitrogen excretion and methane emission in dairy cattle. In: Sauvant, D., Van Milgen, J., Faverdin, P., Friggens, N. (Eds.), Modelling Nutrient Digestion and Utilisation in Farm Animals. Wageningen Academic Publishers, pp. 394-402.

Dormann, C.F., 2007. Promising the future? Global change projections of species distributions. Basic Appl. Ecol. 8, 387-397. http://dx.doi.org/10.1016/j.baae.2006.11.001.

Dunn, R.J.H., Mead, N.E., Willett, K.M., Parker, D.E., 2014. Analysis of heat stress in UK dairy cattle and impact on milk yields. Environ. Res. Lett. 9, 064006.

Duru, M., Adam, M., Cruz, P., Martin, G., Ansquer, P., Ducouytieux, C., Jouany, C., Theau, J.P. Viegas, J., 2009. Modelling above-ground herbage mass for a wide range of grassland community types. Ecol. Model. 220, 209-225. http://dx.doi.org/10.1016/j.ecolmodel. 2008.09.015.

Duru, M., Cruz, P., Martin, G., Theau, J.P., Charron, M.-H., Desange, M., Jouany, C., Zerourou, A., 2010. Herb'sim: un modèle pour raisonner la production et l'utilisation de l'herbe. Fourrages 201, 37-46.

Dury, M., A Hambuckers, P.W., Henrot, A., Favre, E., Ouberdous, M., FranÃ§ois, L., 2011. Responses of European forest ecosystems to 21st century climate: assessing changes in interannual variability and fire intensity. iForest: Biogeosci. For. 4. http://dx.doi.org/ 10.3832/ifor0572-004.

EEA, 2013. EMEP/EEA Air Pollutant Emission Inventory Guidebook. European Environment Agency, Luxembourg.

Elith, J., Leathwick, J.R., 2009. Species distribution models: ecological explanation and prediction across space and time. Annu. Rev. Ecol. Evol. Syst. 40, 677-697. http://dx.doi. org/10.1146/annurev.ecolsys.110308.120159.

El-Maayar, M., Sonnentag, O., 2009. Crop model validation and sensitivity to climate change scenarios. Clim. Res. 39, 47-59. http://dx.doi.org/10.3354/cr00791.

Eory, V., Topp, C.F.E., Moran, D., 2013. Multiple-pollutant cost-effectiveness of greenhouse gas mitigation measures in the UK agriculture. Environ. Sci. Pol. 27, 55-67. http://dx. doi.org/10.1016/j.envsci.2012.11.003.

Eory, V., MacLeod, M., Shrestha, S., Roberts, D., 2014. Linking an economic and a life-cycle analysis biophysical model to support agricultural greenhouse gas mitigation policy. Ger. J. Agric. Econ. 63, 133-142.

Eshel, G., Shepon, A., Makov, T., Milo, R., 2015. Partitioning United States' feed consumption among livestock categories for improved environmental cost assessments. J. Agric. Sci. 153, 432-445. http://dx.doi.org/10.1017/S0021859614000690. 
FACCE-JPI, 2012. Strategic Research Agenda.

FAO, 2012. Sustainability and Organic Livestock Model (SOL-M): Concept Note. FAO Rome.

FAO, 2016. Global Livestock Environmental Assessment Model (GLEAM). Food and Agriculture Organization of the United Nations.

Fischer, E.M., Schar, C., 2010. Consistent geographical patterns of changes in high-impact European heatwaves. Nat. Geosci. 3, 398-403. http://dx.doi.org/10.1038/ngeo866.

Fox, N.J., White, P.C.L., McClean, C.J., Marion, G., Evans, A., Hutchings, M.R., 2011. Predicting impacts of climate change on Fasciola hepatica risk. PLoS ONE 6, e16126. http://dx.doi.org/10.1371/journal.pone.0016126.

Fox, N.J., Marion, G., Davidson, R.S., White, P.C.L., Hutchings, M.R., 2012. Livestock helminths in a changing climate: approaches and restrictions to meaningful predictions. Animals 2, 93.

Fox, N.J., Marion, G., Davidson, R.S., White, P.C.L., Hutchings, M.R., 2013. Modelling parasite transmission in a grazing system: the importance of host behaviour and immunity. PLoS ONE 8, e77996. http://dx.doi.org/10.1371/journal.pone.0077996.

Fox, N.J., Marion, G., Davidson, R.S., White, P.C.L., Hutchings, M.R., 2015. Climate-driven tipping-points could lead to sudden, high-intensity parasite outbreaks. R. Soc. Open Sci. 2.

Gaughan, J., Hahn, L., 2010. Designing and selecting efficient early warning strategies and increasing their efficiencies for animal husbandry. In: Stigter, K. (Ed.), Applied Agrometeorology. Springer, Berlin Heidelberg, pp. 785-790.

Gaughan, J.B., Mader, T.L., Gebremedhin, K.G., 2012. Rethinking heat index tools for livestock. In: Collier, R.J., J.L., C. (Eds.), Environmental Physiology of Livestock. WileyBlackwell, Chichester, pp. 243-265.

Gerber, P.J., Steinfeld, H., Henderson, B., Mottet, A., Opio, C., Dijkman, J., Falcucci, A., Tempio, G., 2013. Tackling Climate Change Through Livestock: A Global Assessment of Emissions and Mitigation Opportunities. FAO, Rome.

Glaesner, N., Helming, K., de Vries, W., 2014. Do current European policies prevent soil threats and support soil functions? Sustain. 6, 9538-9563. http://dx.doi.org/10. 3390/su6129538.

Gorniak, T., Meyer, U., Südekum, K.-H., Dänicke, S., 2014. Impact of mild heat stress on dry matter intake, milk yield and milk composition in mid-lactation Holstein dairy cows in a temperate climate. Arch. Anim. Nutr. 68, 358-369. http://dx.doi.org/10.1080/ 1745039x.2014.950451.

Gottschalk, P., Smith, J.U., Wattenbach, M., Bellarby, J., Stehfest, E., Arnell, N.W., Osborn, T.J., Jones, C., Smith, P., 2012. How will organic carbon stocks in mineral soils evolve under future climate? Global projections using RothC for a range of climate change scenarios. Biogeosciences 9, 3151-3171.

Graux, A.I., Gaurut, M., Agabriel, J., Baumont, R., Delagarde, R., Delaby, L., Soussana, J.F. 2011. Development of the pasture simulation model for assessing livestock production under climate change. Agric. Ecosyst. Environ. 144, 69-91. http://dx.doi.org/10. 1016/j.agee.2011.07.001.

Graux, A.-I., Bellocchi, G., Lardy, R., Soussana, J.-F., 2013. Ensemble modelling of climate change risks and opportunities for managed grasslands in France. Agric. For Meteorol. 170, 114-131. http://dx.doi.org/10.1016/j.agrformet.2012.06.010.

Guisan, A., Thuiller, W., 2005. Predicting species distribution: offering more than simple habitat models. Ecol. Lett. 8, 993-1009. http://dx.doi.org/10.1111/j.1461-0248.2005. 00792.x.

Hammami, H., Bormann, J., M'hamdi, N., Montaldo, H.H., Gengler, N., 2013. Evaluation of heat stress effects on production traits and somatic cell score of Holsteins in a temperate environment. J. Dairy Sci. 96, 1844-1855. http://dx.doi.org/10.3168/jds.2012 5947.

Havlík, P., Valin, H., Herrero, M., Obersteiner, M., Schmid, E., Rufino, M.C., Mosnier, A Thornton, P.K., Böttcher, H., Conant, R.T., Frank, S., Fritz, S., Fuss, S., Kraxner, F. Notenbaert, A., 2014. Climate change mitigation through livestock system transitions. Proc. Natl. Acad. Sci. 111, 3709-3714. http://dx.doi.org/10.1073/pnas.1308044111.

Heikkinen, R.K., Luoto, M., Araújo, M.B., Virkkala, R., Thuiller, W., Sykes, M.T., 2006. Methods and uncertainties in bioclimatic envelope modelling under climate change. Prog. Phys. Geogr. 30, 751-777. http://dx.doi.org/10.1177/0309133306071957.

Henle, K., Alard, D., Clitherow, J., Cobb, P., Firbank, L., Kull, T., McCracken, D., Moritz, R.F.A. Niemelä, J., Rebane, M., Wascher, D., Watt, A., Young, J., 2008. Identifying and managing the conflicts between agriculture and biodiversity conservation in Europe-a review. Agric. Ecosyst. Environ. 124, 60-71. http://dx.doi.org/10.1016/j.agee.2007.09. 005.

Herbut, P., Angrecka, S., 2015. Experimental and model analysis of mechanical ventilation of a milking parlor in summer. Trans. ASABE 58, 1079-1086.

Hidy, D., Barcza, Z., Haszpra, L., Churkina, G., Pinter, K., Nagy, Z., 2012. Development of the biome-BGC model for simulation of managed herbaceous ecosystems. Ecol. Model. 226, 99-119. http://dx.doi.org/10.1016/j.ecolmodel.2011.11.008.

Hijmans, R.J., Graham, C.H., 2006. The ability of climate envelope models to predict the ef fect of climate change on species distributions. Glob. Chang. Biol. 12, 2272-2281. http://dx.doi.org/10.1111/j.1365-2486.2006.01256.x.

Hill, M.J., 2003. Generating generic response signals for scenario calculation of management effects on carbon sequestration in agriculture: approximation of main effects using CENTURY. Environ. Model. Softw. 18, 899-913. http://dx.doi.org/10.1016/ S1364-8152(03)00054-9.

Hill, D.L., Wall, E., 2015. Dairy cattle in a temperate climate: the effects of weather on milk yield and composition depend on management. Animal 9, 138-149. http://dx.doi. org/10.1017/S1751731114002456.

HilleRisLambers, J., Adler, P.B., Harpole, W.S., Levine, J.M., Mayfield, M.M., 2012. Rethinking community assembly through the lens of coexistence theory. Annu. Rev, Ecol. Evol. Syst. 43, 227-248. http://dx.doi.org/10.1146/annurev-ecolsys-110411-160411.

Höglind, M., Bonesmo, H., 2002. Modelling forage quality development in timothy leaves and stems: a mechanistic approach. In: Durand, J.-L (Ed.), Multi-Function Grasslands: Quality Forages, Animal Products and LandscapesProceedings of the 19th General
Meeting of the European Grassland Federation. Association Française pour la Production Fourragère, La Rochelle, France, pp. 27-30.

Höglind, M., Bakken, A.K., Jørgensen, M., Østrem, L., 2010. Tolerance to frost and ice encasement in cultivars of timothy and perennial ryegrass during winter. Grass Forage Sci. 65, 431-445. http://dx.doi.org/10.1111/j.1365-2494.2010.00762.x.

Höglind, M., Thorsen, S.M., Semenov, M.A., 2013. Assessing uncertainties in impact of climate change on grass production in northern Europe using ensembles of global climate models. Agric. For. Meteorol. 170, 103-113. http://dx.doi.org/10.1016/j. agrformet.2012.02.010.

Holzworth, D.P., Snow, V., Janssen, S., Athanasiadis, I.N., Donatelli, M., Hoogenboom, G., White, J.W., Thorburn, P., 2015. Agricultural production systems modelling and software: current status and future prospects. Environ. Model. Softw. 72, 276-286. http://dx.doi.org/10.1016/j.envsoft.2014.12.013.

Howden, S.M., Turnpenny, J., 1998. Working Document 98/03: Modelling Heat Stress and Water Loss of Beef Cattle in Subtropical Queensland Under Current Climates and Climate Change. CSIRO Wildlife and Ecology, Lyneham, Australia.

Huysveld, S., Van linden, V., De Meester, S., Peiren, N., Muylle, H., Lauwers, L., Dewulf, J., 2015. Resource use assessment of an agricultural system from a life cycle perspective - a dairy farm as case study. Agric. Syst. 135, 77-89. http://dx.doi.org/10.1016/j.agsy. 2014.12.008.

IPCC, 2006. Guidelines for National Greenhouse Gas Inventories. Cambridge University Press, Cambridge.

Isbell, F., Calcagno, V., Hector, A., Connolly, J., Harpole, W.S., Reich, P.B., Scherer-Lorenzen, M., Schmid, B., Tilman, D., van Ruijven, J., Weigelt, A., Wilsey, B.J., Zavaleta, E.S., Loreau, M., 2011. High plant diversity is needed to maintain ecosystem services. Nature 477, 199-202. http://dx.doi.org/10.1038/nature10282.

Jégo, G., Belanger, G., Tremblay, G.F., Jing, Q., Baron, V.S., 2013. Calibration and performance evaluation of the STICS crop model for simulating timothy growth and nutritive value. Field Crop Res. 151, 65-77. http://dx.doi.org/10.1016/j.fcr.2013.07.003.

Jégo, G., Chantigny, M., Pattey, E., Belanger, G., Rochette, P., Vanasse, A., Goyer, C., 2014. Improved snow-cover model for multi-annual simulations with the STICS crop model under cold, humid continental climates. Agric. For. Meteorol. 195-196, 38-51. http://dx.doi.org/10.1016/j.agrformet.2014.05.002.

Jing, Q., Belanger, G., Baron, V., Bonesmo, H., Virkajarvi, P., 2013. Simulating the nutritive value of Timothy summer regrowth. Agron. J. 105, 563-572. http://dx.doi.org/10. 2134/agronj2012.0331.

Johst, K., Drechsler, M., Mewes, M., Sturm, A., Wätzold, F., 2015. A novel modeling approach to evaluate the ecological effects of timing and location of grassland conservation measures. Biol. Conserv. 182, 44-52. http://dx.doi.org/10.1016/j.biocon.2014.11. 033.

Jouven, M., Carrere, P., Baumont, R., 2006. Model predicting dynamics of biomass, structure and digestibility of herbage in managed permanent pastures. 1. Model description. Grass Forage Sci. 61, 112-124. http://dx.doi.org/10.1111/j.1365-2494.2006. 00515.x.

Kenyon, F., Sargison, N.D., Skuce, P.J., Jackson, F., 2009. Sheep helminth parasitic disease in south eastern Scotland arising as a possible consequence of climate change. Vet. Parasitol. 163, 293-297. http://dx.doi.org/10.1016/j.vetpar.2009.03.027.

Kipling, R.P., Saetnan, E., Scollan, N., Bartley, D., Bellocchi, G., Hutchings, N.J., Dalgaard, T., van den Pol-van Dasselaar, A., 2014. Modelling livestock and grassland systems under climate change. In: Hopkins, A., Collins, R., Fraser, M., King, V., Lloyd, D., Moorby, J., Robson, P. (Eds.), EGF at 50: The Future of European GrasslandsProceedings of the 25th General Meeting of the European Grassland Federation. Prifysgol Aberystwyth, Aberystwyth, pp. 97-99.

Knapp, A.K., Briggs, J.M., Koelliker, J.K., 2001. Frequency and extent of water limitation to primary production in a mesic temperate grassland. Ecosystems 4, 19-28. http://dx. doi.org/10.1007/s100210000057.

Kochy, M., 2008. Effects of simulated daily precipitation patterns on annual plant populations depend on life stage and climatic region. BMC Ecol. 8, 4. http://dx.doi.org/10. 1186/1472-6785-8-4.

Kreyling, J., Wenigmann, M., Beierkuhnlein, C., Jentsch, A., 2008. Effects of extreme weather events on plant productivity and tissue die-back are modified by community composition. Ecosystems 11, 752-763. http://dx.doi.org/10.1007/s10021-008-9157-9.

Lacetera, N., Segnalini, M., Bernabucci, U., Ronchi, B., Vitali, A., Tran, A., Guis, H., Caminade, C. Calvete, C. Morse, A. Baylis, M. Nardone, A 2013. Climate induced effects on livestock population and productivity in the Mediterranean area. In: Navarra, A., Tubiana, L. (Eds.), Regional Assessment of Climate Change in the Mediterranean. Springer, Netherlands, pp. 135-156

Lardy, R., Bellocchi, G., Soussana, J.F., 2011. A new method to determine soil organic carbon equilibrium. Environ. Model. Softw. 26, 1759-1763. http://dx.doi.org/10.1016/j. envsoft.2011.05.016

Lazzarotto, P., Calanca, P. Fuhrer, J. 2009. Dynamics of grass-clover mixtures-an analysis of the response to management with the PROductive GRASsland Simulator (PROGRASS). Ecol. Model. 220, 703-724. http://dx.doi.org/10.1016/j.ecolmodel. 2008.11.023.

Leclère, D., Jayet, P.-A., de Noblet-Ducoudré, N., 2013. Farm-level autonomous adaptation of European agricultural supply to climate change. Ecol. Econ. 87, 1-14. http://dx.doi. org/10.1016/j.ecolecon.2012.11.010.

Lee, M., Manning, P., Rist, J., Power, S.A., Marsh, C., 2010. A global comparison of grassland biomass responses to $\mathrm{CO}_{2}$ and nitrogen enrichment. Philos. Trans. R. Soc., B 365 , 2047-2056. http://dx.doi.org/10.1098/rstb.2010.0028.

Leip, A., Weiss, F., Wassenaar, T., Perez, I., Fellmann, T., Loudjani, P., Tubiello, F., Grandgirard, D. Monni, S., Biala, K, 2010. Evaluation of the Livestock Sector's Contribution to the EU Greenhouse Gas Emissions (GGELS) (Brussels).

Lemaire, G., Wilkins, R., Hodgson, J., 2005. Challenges for grassland science: managing research priorities. Agric. Ecosyst. Environ. 108, 99-108. http://dx.doi.org/10.1016/j. agee.2005.01.003. 
Lessard, J.-P., Belmaker, J., Myers, J.A., Chase, J.M., Rahbek, C., 2012. Inferring local ecological processes amid species pool influences. Trends Ecol. Evol. 27, 600-607. http://dx. doi.org/10.1016/j.tree.2012.07.006

Li, C., Frolking, S., Frolking, T.A., 1992. A model of nitrous-oxide evolution fromsoil driven by rainfall events. 1. Model structure and sensitivity. J. Geophys. Res.-Atmos. 97 9759-9776.

Li, C., Frolking, S., Harriss, R., 1994. Modeling carbon biogeochemistry in agricultural soils. Glob. Biogeochem. Cycles 8, 237-254. http://dx.doi.org/10.1029/94gb00767.

Li, F.Y., Snow, V.O., Holzworth, D.P., 2011. Modelling the seasonal and geographical pattern of pasture production in New Zealand. N. Z. J. Agric. Res. 54, 331-352. http:// dx.doi.org/10.1080/00288233.2011.613403.

Li, C., Salas, W., Zhang, R., Krauter, C., Rotz, A., Mitloehner, F., 2012. Manure-DNDC: a biogeochemical process model for quantifying greenhouse gas and ammonia emissions from livestock manure systems. Nutr. Cycl. Agroecosyst. 93, 163-200. http://dx.doi. org/10.1007/s10705-012-9507-z.

Lu, C., Tian, H., 2013. Net greenhouse gas balance in response to nitrogen enrichment: perspectives from a coupled biogeochemical model. Glob. Chang. Biol. 19, 571-588. http://dx.doi.org/10.1111/gcb.12049.

Lugato, E., Panagos, P., Bampa, F., Jones, A., Montanarella, L., 2014. A new baseline of organic carbon stock in European agricultural soils using a modelling approach. Glob. Chang. Biol. 20, 313-326. http://dx.doi.org/10.1111/gcb.12292.

Ma, S., Lardy, R., Graux, A.-I., B.T., H., Klumpp, K., Martin, R., Bellocchi, G., 2015. Regionalscale analysis of carbon and water cycles on managed grassland systems. Environ. Model Softw. http://dx.doi.org/10.1016/j.envsoft.2015.03.007.

Maes, J., Paracchini, M.L., Zulian, G., Dunbar, M.B., Alkemade, R., 2012. Synergies and trade-offs between ecosystem service supply, biodiversity, and habitat conservation status in Europe. Biol. Conserv. 155, 1-12. http://dx.doi.org/10.1016/j.biocon.2012. 06.016.

Maire, V., Soussana, J.-F., Gross, N., Bachelet, B., Pagès, L., Martin, R., Reinhold, T., Wirth, C., Hill, D., 2013. Plasticity of plant form and function sustains productivity and dominance along environment and competition gradients. A modeling experiment with Gemini. Ecol. Model. 254, 80-91. http://dx.doi.org/10.1016/j.ecolmodel.2012.03.039.

Marquer, P., Rabade, T., Forti, R., 2014. Eurostat: Statistics Explained - Meat Production Statistics. EC.

Marriott, C.A., Fothergill, M., Jeangros, B., Scotton, M., Louault, F., 2004. Long-term impacts of extensification of grassland management on biodiversity and productivity in upland areas. A review. Agronomie 24, 447-461. http://dx.doi.org/10.1051/agro: 2004041.

Martin, G., Martin-Clouaire, R., Duru, M., 2013. Farming system design to feed the changing world. A review. Agron. Sustain. Dev. 33, 131-149. http://dx.doi.org/10.1007/ s13593-011-0075-4.

Martre, P., Wallach, D., Asseng, S., Ewert, F., Jones, J.W., Rötter, R.P., Boote, K.J., Ruane, A.C., Thorburn, P.J., Cammarano, D., Hatfield, J.L., Rosenzweig, C., Aggarwal, P.K., Angulo, C. Basso, B., Bertuzzi, P., Biernath, C., Brisson, N., Challinor, A.J., Doltra, J., Gayler, S. Goldberg, R., Grant, R.F., Heng, L., Hooker, J., Hunt, L.A., Ingwersen, J., Izaurralde, R.C., Kersebaum, K.C., Müller, C., Kumar, S.N., Nendel, C., O'Leary, G., Olesen, J.E., Osborne, T.M., Palosuo, T., Priesack, E., Ripoche, D., Semenov, M.A., Shcherbak, I., Steduto, P., Stöckle, C.O., Stratonovitch, P., Streck, T., Supit, I., Tao, F., Travasso, M., Waha, K., White, J.W., Wolf, J., 2015. Multimodel ensembles of wheat growth: many models are better than one. Glob. Chang. Biol. 21, 911-925. http://dx.doi.org/ 10.1111/gcb.12768.

Matthews, K.B., Rivington, M., Blackstock, K., McCrum, G., Buchan, K., Miller, D.G., 2011. Raising the bar? - the challenges of evaluating the outcomes of environmental modelling and software. Environ. Model. Softw. 26, 247-257. http://dx.doi.org/10. 1016/j.envsoft.2010.03.031.

Meier, M.S., Stoessel, F., Jungbluth, N., Juraske, R., Schader, C., Stolze, M., 2015. Environmental impacts of organic and conventional agricultural products - are the differences captured by life cycle assessment? J. Environ. Manag. 149, 193-208. http:// dx.doi.org/10.1016/j.jenvman.2014.10.006.

Meul, M., Van Middelaar, C.E., de Boer, I.J.M., Van Passel, S., Fremaut, D., Haesaert, G., 2014. Potential of life cycle assessment to support environmental decision making at commercial dairy farms. Agric. Syst. 131, 105-115. http://dx.doi.org/10.1016/j.agsy.2014. 08.006 .

Mewes, M., Drechsler, M., Johst, K., Sturm, A., Wätzold, F., 2015. A systematic approach for assessing spatially and temporally differentiated opportunity costs of biodiversity conservation measures in grasslands. Agric. Syst. 137, 76-88. http://dx.doi.org/10. 1016/j.agsy.2015.03.010.

Miranda, N.D., Tuomisto, H.L., McCulloch, M.D., 2015. Meta-analysis of greenhouse gas emissions from anaerobic digestion processes in dairy farms. Environ. Sci. Technol. 49, 5211-5219. http://dx.doi.org/10.1021/acs.est.5b00018.

Mitchell, M.A., 2006. Using physiological models to define environmental control strategies. In: Gous, R., Fisher, C., Morris, T.R. (Eds.), Mechanistic Modelling in Pig and Poultry Production. CAB International, Wallingford, Oxford, pp. 209-228.

Morignat, E., Gay, E., Vinard, J.-L., Calavas, D., Hénaux, V., 2015. Quantifying the influence of ambient temperature on dairy and beef cattle mortality in France from a time-series analysis. Environ. Res. 140, 524-534. http://dx.doi.org/10.1016/j.envres.2015.05. 001.

Mouysset, L., Doyen, L., Pereau, J.-C., Jiguet, F., 2014. Benefits and costs of biodiversity in agricultural public policies. Eur. Rev. Agric. Econ. http://dx.doi.org/10.1093/erae/ jbu005.

Nardone, A., Ronchi, B., Lacetera, N., Ranieri, M.S., Bernabucci, U., 2010. Effects of climate changes on animal production and sustainability of livestock systems. Livest. Sci. 130, 57-69. http://dx.doi.org/10.1016/j.livsci.2010.02.011.

Nayak, D., Saetnan, E., Cheng, K., Wang, W., Koslowski, F., Cheng, Y.-F., Zhu, W.Y., Wang, J.K., Liu, J.-X., Moran, D., Yan, X., Cardenas, L., Newbold, J., Pan, G., Lu, Y., Smith, P., 2015. Management opportunities to mitigate greenhouse gas emissions from Chinese agriculture. Agric. Ecosyst. Environ. 209, 108-124. http://dx.doi.org/10.1016/j.agee. 2015.04.035.

Neef, A., Neubert, D., 2011. Stakeholder participation in agricultural research projects: a conceptual framework for reflection and decision-making. Agric. Hum. Values 28, 179-194. http://dx.doi.org/10.1007/s10460-010-9272-z.

Nelson, E., Mendoza, G., Regetz, J., Polasky, S., Tallis, H., Cameron, D., Chan, K.M.A., Daily, G.C., Goldstein, J., Kareiva, P.M., Lonsdorf, E., Naidoo, R., Ricketts, T.H., Shaw, M., 2009. Modeling multiple ecosystem services, biodiversity conservation, commodity production, and tradeoffs at landscape scales. Front. Ecol. Environ. 7, 4-11. http:// dx.doi.org/10.1890/080023.

Nelson, G.C., van der Mensbrugghe, D., Ahammad, H., Blanc, E., Calvin, K., Hasegawa, T. Havlik, P., Heyhoe, E., Kyle, P., Lotze-Campen, H., von Lampe, M., Mason d'Croz, D. van Meijl, H., Müller, C., Reilly, J., Robertson, R., Sands, R.D., Schmitz, C., Tabeau, A. Takahashi, K., Valin, H., Willenbockel, D., 2014. Agriculture and climate change in global scenarios: why don't the models agree. Agric. Econ. 45, 85-101. http://dx. doi.org/10.1111/agec.12091.

O'Brien, D., Shalloo, L., Patton, J., Buckley, F., Grainger, C., Wallace, M., 2012. Evaluation of the effect of accounting method, IPCC $\mathrm{v}$. LCA, on grass-based and confinement dairy systems' greenhouse gas emissions. Animal 6, 1512-1527. http://dx.doi.org/10. 1017/S1751731112000316.

O'Connor, L.J., Walkden-Brown, S.W., Kahn, L.P., 2006. Ecology of the free-living stages of major trichostrongylid parasites of sheep. Vet. Parasitol. 142, 1-15. http://dx.doi.org/ 10.1016/j.vetpar.2006.08.035

Oliver, T.H., Heard, M.S., Isaac, N.J.B., Roy, D.B., Procter, D., Eigenbrod, F., Freckleton, R. Hector, A., Orme, C.D.L., Petchey, O.L., Proença, V., Raffaelli, D., Suttle, K.B., Mace, G.M., Martín-López, B., Woodcock, B.A., Bullock, J.M., 2015. Biodiversity and resilience of ecosystem functions. Trends Ecol. Evol. 30, 673-684. http://dx.doi.org/10.1016/j. tree.2015.08.009.

Opio, C., Gerber, P., Mottet, A., Falcucci, A., Tempio, G., Macleod, M., Vellinga, T. Henderson, B., Steinfeld, H., 2013. Greenhouse Gas Emissions From Ruminant Supply Chains: A Global Life Cycle Assessment (Rome).

Pagel, J., Schurr, F.M., 2012. Forecasting species ranges by statistical estimation of ecological niches and spatial population dynamics. Glob. Ecol. Biogeogr. 21, 293-304. http:// dx.doi.org/10.1111/j.1466-8238.2011.00663.x.

Parton, W.J., Hartman, M.D., Ojima, D.S., Schimel, D.S., 1998. DAYCENT and its land surface sub-model: description and testing. Glob. Planet. Chang. 19, 35-48. http://dx.doi.org/ 10.1016/S0921-8181(98)00040-X.

Perego, A., Giussani, A., Sanna, M., Fumagalli, M., Carozzi, M., Alfieri, L., Brenna, S., Acutis M., 2013. The ARMOSA simulation crop model: overall features, calibration and validation results. Ital. J. Agrometeorol. 18, 23-38.

Peterson, P.R., Sheaffer, C.C., Hall, M.H., 1992. Drought effects on perennial forage legume yield and quality. Agron. J. 84, 774-779.

Popp, A., Humpenoder, F., Weindl, I., Bodirsky, B.L., Bonsch, M., Lotze-Campen, H., Muller, C., Biewald, A., Rolinski, S., Stevanovic, M., Dietrich, J.P., 2014. Land-use protection for climate change mitigation. Nat. Clim. Chang. 4, 1095-1098. http://dx.doi.org/10 1038/nclimate2444.

Purse, B.V., Mellor, P.S., Rogers, D.J., Samuel, A.R., Mertens, P.P.C., Baylis, M., 2005. Climate change and the recent emergence of bluetongue in Europe. Nat. Rev. Microbiol. 3, 171-181. http://dx.doi.org/10.1038/nrmicro1090.

Radoń, J., Bieda, W., Lendelová, J., Pogran, Š., 2014. Computational model of heat exchange between dairy cow and bedding. Comput. Electron. Agric. 107, 29-37. http://dx.doi. org/10.1016/j.compag.2014.06.006.

Ripple, W.J., Smith, P., Haberl, H., Montzka, S.A., McAlpine, C., Boucher, D.H., 2014. Ruminants, climate change and climate policy. Nat. Clim. Chang. 4, 2-5. http://dx.doi.org/ 10.1038/nclimate2081.

Robertson, M.P., Peter, C.I., Villet, M.H., Ripley, B.S., 2003. Comparing models for predicting species' potential distributions: a case study using correlative and mechanistic predictive modelling techniques. Ecol. Model. 164, 153-167. http://dx.doi.org/10.1016 S0304-3800(03)00028-0.

Robertson, A.D., Davies, C.A., Smith, P., Dondini, M., McNamara, N.P., 2015. Modelling the carbon cycle of Miscanthus plantations: existing models and the potential for their improvement. GCB Bioenergy 7, 405-421. http://dx.doi.org/10.1111/gcbb.12144.

Rodela, R., Cundill, G., Wals, A.E.J., 2012. An analysis of the methodological underpinnings of social learning research in natural resource management. Ecol. Econ. 77, 16-26. http://dx.doi.org/10.1016/j.ecolecon.2012.02.032.

Rotz, C.A., Montes, F., Hafner, S.D., Heber, A.J., Grant, R.H., 2014. Ammonia emission model for whole farm evaluation of dairy production systems. J. Environ. Qual. 43, 1143-1158. http://dx.doi.org/10.2134/jeq2013.04.0121.

Ryals, R., Hartman, M.D., Parton, W.J., DeLonge, M.S., Silver, W.L., 2015. Long-term climate change mitigation potential with organic matter management on grasslands. Ecol. Appl. 25, 531-545. http://dx.doi.org/10.1890/13-2126.1.

Scherr, S., Shames, S., Friedman, R., 2012. From climate-smart agriculture to climate-smart landscapes. Agric. Food Secur. 1, 1-15. http://dx.doi.org/10.1186/2048-7010-1-12.

Schils, R.L.M., de Haan, M.H.A., Hemmer, J.G.A., van den Pol-van Dasselaar, A., de Boer, J.A., Evers, A.G., Holshof, G., van Middelkoop, J.C., Zom, R.L.G., 2007. DairyWise, a wholefarm dairy model. J. Dairy Sci. 90, 5334-5346. http://dx.doi.org/10.3168/jds.2006842.

Schmitz, C. van Meijl, H., Kyle, P., Nelson, G.C., Fujimori, S., Gurgel, A., Havlik, P., Heyhoe, E., d'Croz, D.M., Popp, A., Sands, R., Tabeau, A., van der Mensbrugghe, D., von Lampe M., Wise, M., Blanc, E., Hasegawa, T., Kavallari, A., Valin, H., 2014. Land-use change trajectories up to 2050: insights from a global agro-economic model comparison. Agric. Econ. 45, 69-84. http://dx.doi.org/10.1111/agec.12090.

Schneider, U.A., Havlík, P., Schmid, E., Valin, H., Mosnier, A., Obersteiner, M., Böttcher, H. Skalský, R., Balkovič, J., Sauer, T., Fritz, S., 2011. Impacts of population growth, economic development, and technical change on global food production and consumption. Agric. Syst. 104, 204-215. http://dx.doi.org/10.1016/j.agsy.2010.11.003. 
Scholten, M.C.T., 2015. Research and innovation for a competitive and sustainable anima production sector in a climate changing Europe: linking up MACSUR with Animal Task Force. Adv. Anim. Biosci. 6, 1-2.

Schönhart, M., Nadeem, I., 2015. Direct climate change impacts on cattle indicated by TH models. Adv. Anim. Biosci. 6, 17-20. http://dx.doi.org/10.1017/S2040470014000430.

Schönhart, M., Schauppenlehner, T., Schmid, E., 2011. Integrated bio-economic farm modeling for biodiversity assessment at landscape level. In: Flichman, G. (Ed.), BioEconomic Models Applied to Agricultural Systems. Springer, Netherlands, pp. 185-213.

Segnalini, M., Bernabucci, U., Vitali, A., Nardone, A., Lacetera, N., 2013. Temperature humidity index scenarios in the Mediterranean basin. Int. J. Biometeorol. 57, 451-458. http://dx.doi.org/10.1007/s00484-012-0571-5.

Siedlok, F., Hibbert, P., 2014. The organization of interdisciplinary research: modes, drivers and barriers. Int. J. Manag. Rev. 16, 194-210. http://dx.doi.org/10.1111/ijmr. 12016.

Silanikove, N., Koluman, N., 2015. Impact of climate change on the dairy industry in temperate zones: predications on the overall negative impact and on the positive role of dairy goats in adaptation to earth warming. Small Rumin. Res. 123, 27-34. http://dx. doi.org/10.1016/j.smallrumres.2014.11.005.

Smith, P., Smith, J.U., Powlson, D.S., McGill, W.B., Arah, J.R.M., Chertov, O.G., Coleman, K. Franko, U., Frolking, S., Jenkinson, D.S., Jensen, L.S., Kelly, R.H., Klein-Gunnewiek, H. Komarov, A.S., Li, C., Molina, J.A.E., Mueller, T., Parton, W.J., Thornley, J.H.M. Whitmore, A.P., 1997. A comparison of the performance of nine soil organic matter models using datasets from seven long-term experiments. Geoderma 81, 153-225. http://dx.doi.org/10.1016/S0016-7061(97)00087-6.

Smith, P., Falloon, P.D., Körschens, M., Shevtsova, L.K., Franko, U., Romanenkov, V., Coleman, K., Rodionova, V., Smith, J.U., Schramm, G., 2002. EuroSOMNET - a European database of long-term experiments on soil organic matter: the WWW metadatabase. J. Agric. Sci. 138, 123-134. http://dx.doi.org/10.1017/S0021859601001800.

Smith, L.A., Marion, G., Swain, D.L., White, P.C.L., Hutchings, M.R., 2009. The effect of grazing management on livestock exposure to parasites via the faecal-oral route. Prev. Vet. Med. 91, 95-106. http://dx.doi.org/10.1016/j.prevetmed.2009.05.026.

Snow, V.O., Rotz, C.A., Moore, A.D., Martin-Clouaire, R., Johnson, I.R., Hutchings, N.J., Eckard, R.J., 2014. The challenges - and some solutions - to process-based modelling of grazed agricultural systems. Environ. Model. Softw. 62, 420-436. http://dx.doi.org/ 10.1016/j.envsoft.2014.03.009.

Sommer, S.G., Olesen, J.E., Petersen, S.O., Weisbjerg, M.R., Valli, L., Rodhe, L., BÉLine, F. 2009. Region-specific assessment of greenhouse gas mitigation with different manure management strategies in four agroecological zones. Glob. Chang. Biol. 15, 2825-2837. http://dx.doi.org/10.1111/j.1365-2486.2009.01888.

Soussana, J.-F., 2014. Research priorities for sustainable agri-food systems and life cycle assessment. J. Clean. Prod. 73, 19-23. http://dx.doi.org/10.1016/j.jclepro.2014.02.061.

Soussana, J.F., Allard, V., Pilegaard, K., Ambus, P., Amman, C., Campbell, C., Ceschia, E. Clifton-Brown, J., Czobel, S., Domingues, R., Flechard, C., Fuhrer, J., Hensen, A, Horvath, L., Jones, M., Kasper, G., Martin, C., Nagy, Z., Neftel, A., Raschi, A., Baronti, S., Rees, R.M., Skiba, U., Stefani, P., Manca, G., Sutton, M., Tuba, Z., Valentini, R. 2007. Full accounting of the greenhouse gas $\left(\mathrm{CO}_{2}, \mathrm{~N}_{2} \mathrm{O}, \mathrm{CH}_{4}\right)$ budget of nine European grassland sites. Agric. Ecosyst. Environ. 121, 121-134. http://dx.doi.org/10.1016/j. agee.2006.12.022

Soussana, J.F., Tallec, T., Blanfort, V., 2010. Mitigating the greenhouse gas balance of ruminant production systems through carbon sequestration in grasslands. Animal 4 334-350. http://dx.doi.org/10.1017/S1751731109990784.

Soussana, J.-F., Fereres, E., Long, S.P., Mohren, F.G.M.J., Pandya-Lorch, R., Peltonen-Sainio, P., Porter, J.R., Rosswall, T., von Braun, J., 2012a. A European science plan to sustainably increase food security under climate change. Glob. Chang. Biol. 18, 3269-3271. http://dx.doi.org/10.1111/j.1365-2486.2012.02746.x.

Soussana, J.-F., Maire, V., Gross, N., Bachelet, B., Pagès, L., Martin, R., Hill, D., Wirth, C. 2012b. Gemini: a grassland model simulating the role of plant traits for community dynamics and ecosystem functioning. Parameterization and evaluation. Ecol. Model. 231, 134-145. http://dx.doi.org/10.1016/j.ecolmodel.2012.02.002.

Sterk, B., van Ittersum, M.K., Leeuwis, C., 2011. How, when, and for what reasons does land use modelling contribute to societal problem solving? Environ. Model. Softw. 26, 310-316. http://dx.doi.org/10.1016/j.envsoft.2010.06.004.

Stromberg, B.E., 1997. Environmental factors influencing transmission. Vet. Parasitol. 72 247-264. http://dx.doi.org/10.1016/S0304-4017(97)00100-3.

Tatem, A.J., Baylis, M., Mellor, P.S., Purse, B.V., Capela, R., Pena, I., Rogers, D.J., 2003. Prediction of bluetongue vector distribution in Europe and north Africa using satellite imagery. Vet. Microbiol. 97, 13-29. http://dx.doi.org/10.1016/j.vetmic.2003.08.009.

Tedeschi, L.O., Cavalcanti, L.F.L., Fonseca, M.A., Herrero, M., Thornton, P.K., 2014. The evolution and evaluation of dairy cattle models for predicting milk production: an agricultural model intercomparison and improvement project (AgMIP) for livestock. Anim. Prod. Sci. 54, 2052-2067. http://dx.doi.org/10.1071/AN14620.

Thompson, V.A., Barioni, L.G., Rumsey, T.R., Fadel, J.G., Sainz, R.D., 2014. The development of a dynamic, mechanistic, thermal balance model for Bos indicus and Bos taurus. J. Agric. Sci. 152, 464-482. http://dx.doi.org/10.1017/S002185961300049X

Thornton, P.K., 2010. Livestock production: recent trends, future prospects. Philos. Trans R. Soc., B 365, 2853-2867. http://dx.doi.org/10.1098/rstb.2010.0134.

Thorsen, S.M., Höglind, M., 2010a. Assessing winter survival of forage grasses in Norway under future climate scenarios by simulating potential frost tolerance in combination with simple agroclimatic indices. Agric. For. Meteorol. 150, 1272-1282. http://dx.doi. org/10.1016/j.agrformet.2010.05.010.

Thorsen, S.M., Höglind, M., 2010b. Modelling cold hardening and dehardening in timothy. Sensitivity analysis and Bayesian model comparison. Agric. For. Meteorol. 150, 1529-1542. http://dx.doi.org/10.1016/j.agrformet.2010.08.001.

Tian, H., Melillo, J., Lu, C., Kicklighter, D., Liu, M., Ren, W., Xu, X., Chen, G., Zhang, C., Pan, S. Liu, J., Running, S., 2011. China's terrestrial carbon balance: contributions from multiple global change factors. Glob. Biogeochem. Cycles 25. http://dx.doi.org/10. 1029/2010gb003838.

Tilman, D., Clark, M., 2014. Global diets link environmental sustainability and human health. Nature 515, 518-522. http://dx.doi.org/10.1038/nature13959.

Tixier, P., Peyrard, N., Aubertot, J.-N., Gaba, S., Radoszycki, J., Caron-Lormier, G., Vinatier, F., Mollot, G., Sabbadin, R., 2013. Modelling interaction networks for enhanced ecosystem services in agroecosystems. Adv. Ecol. Res. 49, 437-480. http://dx.doi.org/10. 1016/B978-0-12-420002-9.00007-X

Valdivia, R.O., Antle, J.M., Claessens, L., Nelson, G.C., Rosenzweig, C., Ruane, A.C., Vervoort, J., 2013. Representative Agricultural Pathways and Scenarios: A Trans-Disciplinary Approach to Agricultural Model Inter-Comparison, Improvement and Climate Impact Assessment, Water, Food, Energy and Innovation for a Sustainable World: ASA, CSSA and SSSA International Annual Meetings. ASA, CSSA and SSSA, Tampa, Florida.

Valin, H., Sands, R.D., van der Mensbrugghe, D., Nelson, G.C., Ahammad, H., Blanc, E., Bodirsky, B., Fujimori, S., Hasegawa, T., Havlik, P., Heyhoe, E., Kyle, P., Mason-D'Croz, D., Paltsev, S., Rolinski, S., Tabeau, A., van Meijl, H., von Lampe, M., Willenbockel, D., 2014. The future of food demand: understanding differences in global economic models. Agric. Econ. 45, 51-67. http://dx.doi.org/10.1111/agec.12089.

van Dijk, J., David, G.P., Baird, G., Morgan, E.R., 2008. Back to the future: developing hypotheses on the effects of climate change on ovine parasitic gastroenteritis from historical data. Vet. Parasitol. 158, 73-84. http://dx.doi.org/10.1016/j.vetpar.2008.08.006.

van Dijk, J., de Louw, M.D.E., Kalis, L.P.A., Morgan, E.R., 2009. Ultraviolet light increases mortality of nematode larvae and can explain patterns of larval availability at pasture. Int. J. Parasitol. 39, 1151-1156. http://dx.doi.org/10.1016/j.ijpara.2009.03.004.

van Latesteijn, H.C., 1999. Land Use in Europe - A Methodology for Policy-Oriented Future Studies. Sdu Uitgevers, The Hague.

van Oijen, M., Balkovič, J., Beer, C., Cameron, D.R., Ciais, P., Cramer, W., Kato, T., Kuhnert, M., Martin, R., Myneni, R., Rammig, A., Rolinski, S., Soussana, J.F., Thonicke, K., Van der Velde, M., Xu, L., 2014. Impact of droughts on the carbon cycle in European vegetation: a probabilistic risk analysis using six vegetation models. Biogeosciences 11 , 6357-6375. http://dx.doi.org/10.5194/bg-11-6357-2014.

van Paassen, A., Roetter, R.P., van Keulen, H., Hoanh, C.T., 2007. Can computer models stimulate learning about sustainable land use? Experience with LUPAS in the humid (sub-)tropics of Asia. Agric. Syst. 94, 874-887. http://dx.doi.org/10.1016/j. agsy.2006.11.012.

Vital, J.-A., Gaurut, M., Lardy, R., Viovy, N., Soussana, J.-F., Bellocchi, G., Martin, R., 2013. High-performance computing for climate change impact studies with the pasture simulation model. Comput. Electron. Agric. 98, 131-135. http://dx.doi.org/10.1016/j. compag.2013.08.004.

Vitali, A., Segnalini, M., Bertocchi, L., Bernabucci, U., Nardone, A., Lacetera, N., 2009. Seasonal pattern of mortality and relationships between mortality and temperature-humidity index in dairy cows. J. Dairy Sci. 92, 3781-3790. http://dx.doi.org/10.3168/jds. 2009-2127.

Voinov, A., Bousquet, F., 2010. Modelling with stakeholders. Environ. Model. Softw. 25, 1268-1281. http://dx.doi.org/10.1016/j.envsoft.2010.03.007.

von Lampe, M., Willenbockel, D., Ahammad, H., Blanc, E., Cai, Y., Calvin, K., Fujimori, S., Hasegawa, T. Havlik, P., Heyhoe, E., Kyle, P., Lotze-Campen, H., Mason d'Croz, D. Nelson, G.C., Sands, R.D., Schmitz, C., Tabeau, A., Valin, H., van der Mensbrugghe, D., van Meijl, H., 2014. Why do global long-term scenarios for agriculture differ? An overview of the AgMIP global economic model intercomparison. Agric. Econ. 45, 3-20. http://dx.doi.org/10.1111/agec.12086.

Waha, K., van Bussel, L.G.J., Mueller, C., Bondeau, A., 2012. Climate-driven simulation of global crop sowing dates. Glob. Ecol. Biogeogr. 21, 247-259. http://dx.doi.org/10. 1111/j.1466-8238.2011.00678x.

Weiske, A., Vabitsch, A., Olesen, J.E., Schelde, K., Michel, J., Friedrich, R., Kaltschmitt, M., 2006. Mitigation of greenhouse gas emissions in European conventional and organic dairy farming. Agric. Ecosyst. Environ. 112, 221-232. http://dx.doi.org/10.1016/j.agee.2005.08.023.

Williams, J.R., Arnold, J.G., Kiniry, J.R., Gassman, P.W., Green, C.H., 2008. History of model development at Temple, Texas. Hydrol. Sci. J. 53, 948-960. http://dx.doi.org/10.1623/ hysj.53.5.948.

Wilson, A., Mellor, P., 2008. Bluetongue in Europe: vectors, epidemiology and climate change. Parasitol. Res. 103, 69-77. http://dx.doi.org/10.1007/s00436-008-1053-x.

Woodward, S.J.R., 2001. Validating a model that predicts daily growth and feed quality of New Zealand dairy pastures. Environ. Int. 27, 133-137. http://dx.doi.org/10.1016/ s0160-4120(01)00073-3.

Wu, L., McGechan, M.B., McRoberts, N., Baddeley, J.A., Watson, C.A., 2007. SPACSYS: integration of a 3D root architecture component to carbon, nitrogen and water cyclingmodel description. Ecol. Model. 200, 343-359. http://dx.doi.org/10.1016/j. ecolmodel.2006.08.010

Yagasaki, Y., Shirato, Y., 2013. Rates and potentials of soil organic carbon sequestration in agricultural lands in Japan: an assessment using a process-based model and spatiallyexplicit land-use change inventories. Biogeosci. Discuss. 10, 18359-18406. http://dx. doi.org/10.5194/bgd-10-18359-2013.

Yagasaki, Y., Shirato, Y., 2014. Assessment on the rates and potentials of soil organic carbon sequestration in agricultural lands in Japan using a process-based model and spatially explicit land-use change inventories - part 2: future potentials. Biogeosciences $11,4443-4457$

Yeluripati, J.B., del Prado, A., Sanz-Cobeña, A., Rees, R.M., Li, C., Chadwick, D., Tilston, E., Topp, C.F.E., Cardenas, L.M., Ingraham, P., Gilhespy, S., Anthony, S., Vetter, S.H., Misselbrook, T., Salas, W., Smith, P., 2015. Global research alliance modelling platform (GRAMP): an open web platform for modelling greenhouse gas emissions from agroecosystems. Comput. Electron. Agric. 111, 112-120. http://dx.doi.org/10.1016/j. compag.2014.11.016.

Zobel, M., 2015. The species pool concept as a framework for studying patterns of plant diversity. J. Veg. Sci. http://dx.doi.org/10.1111/jvs.12333 (Published online). 